\title{
Transcriptome analysis reveals a molecular understanding of nicotinamide and butyrate sodium on meat quality of broilers under high stocking density
}

Yuqin Wu, Youli Wang, Dafei Yin, Tahir Mahmood and Jianmin Yuan ${ }^{*}$

\begin{abstract}
Background: In recent years, increased attention has been focused on breast muscle yield and meat quality in poultry production. Supplementation with nicotinamide and butyrate sodium can improve the meat quality of broilers. However, the potential molecular mechanism is not clear yet. This study was designed to investigate the effects of supplementation with a combination of nicotinamide and butyrate sodium on breast muscle transcriptome of broilers under high stocking density. A total of 300 21-d-old Cobb broilers were randomly allocated into 3 groups based on stocking density: low stocking density control group $\left(L ; 14\right.$ birds $\left./ \mathrm{m}^{2}\right)$, high stocking density control group $(H$; $18 \mathrm{birds} / \mathrm{m}^{2}$ ), and high stocking density group provided with a combination of $50 \mathrm{mg} / \mathrm{kg}$ nicotinamide and $500 \mathrm{mg} / \mathrm{kg}$ butyrate sodium (COMB; 18 birds $/ \mathrm{m}^{2}$ ), raised to 42 days of age.
\end{abstract}

Results: The H group significantly increased cooking losses, $\mathrm{pH}$ decline and activity of lactate dehydrogenase in breast muscle when compared with the $L$ group. COMB showed a significant decrease in these indices by comparison with the $\mathrm{H}$ group $(P<0.05)$. The transcriptome results showed that key genes involved in glycolysis, proteolysis and immune stress were up-regulated whereas those relating to muscle development, cell adhesion, cell matrix and collagen were down-regulated in the $\mathrm{H}$ group as compared to the L group. In contrast, genes related to muscle development, hyaluronic acid, mitochondrial function, and redox pathways were up-regulated while those associated with inflammatory response, acid metabolism, lipid metabolism, and glycolysis pathway were down-regulated in the COMB group when compared with the $\mathrm{H}$ group.

Conclusions: The combination of nicotinamide and butyrate sodium may improve muscle quality by enhancing mitochondrial function and antioxidant capacity, inhibiting inflammatory response and glycolysis, and promoting muscle development and hyaluronic acid synthesis.

Keywords: Stocking density, Broiler, Nicotinamide, Butyrate sodium, Transcriptome

\footnotetext{
* Correspondence: yuanjm@cau.edu.cn

State Key Laboratory of Animal Nutrition, College of Animal Science and

Technology, China Agricultural University, Beijing 100193, China
}

(C) The Author(s). 2020 Open Access This article is licensed under a Creative Commons Attribution 4.0 International License, which permits use, sharing, adaptation, distribution and reproduction in any medium or format, as long as you give appropriate credit to the original author(s) and the source, provide a link to the Creative Commons licence, and indicate if changes were made. The images or other third party material in this article are included in the article's Creative Commons licence, unless indicated otherwise in a credit line to the material. If material is not included in the article's Creative Commons licence and your intended use is not permitted by statutory regulation or exceeds the permitted use, you will need to obtain permission directly from the copyright holder. To view a copy of this licence, visit http://creativecommons.org/licenses/by/4.0/ The Creative Commons Public Domain Dedication waiver (http://creativecommons.org/publicdomain/zero/1.0/) applies to the data made available in this article, unless otherwise stated in a credit line to the data. 


\section{Background}

Intensive stocking in the rapidly developing poultry industry worldwide has become a norm. However, high stocking density causes oxidative stress in broilers [1] and reduces the tenderness and increases the drip loss of breast muscle $[2,3]$. Oxidation is one of the leading reasons for the deterioration of meat quality [4], and oxidative stress causes protein and lipid peroxidation as well as cellular damage $[5,6]$ which ultimately affects meat quality [7]. Nicotinamide (NAM) reduces oxidative stress and inhibits reactive oxygen species (ROS) production $[8,9]$. Dietary supplementation with NAM has been observed to minimize the formation of carbonylated proteins in the liver of high-fat fed mice [10]. Butyrate sodium (BA) could also improve antioxidant capacity in a human study [11]. Further, the addition of BA can enhance the activities of superoxide dismutase and catalase and reduce the level of malondialdehyde in serum [12]. Butyrate treatment has been reported to decrease the levels of markers of oxidative stress and apoptosis in mice [13]. As treatment with NAM and BA both can elevate antioxidant capacity and muscle function, it may improve the muscle quality of broilers under high stocking density. Dietary supplementation with $60 \mathrm{mg} / \mathrm{kg}$ niacin (NAM precursor) reduces the drip loss of breast muscles in broilers [14]. Dietary supplementation with BA can increase broiler weight, decrease abdominal fat percentage [15], and reduce intramuscular fat content [16].

Mitochondrial biogenesis has previously been associated with preservation of muscle mass and beneficial effects on metabolism [17]. Peroxisome proliferator-activated receptor- $\gamma$ coactivator $1 \alpha(\mathrm{PGC} 1 \alpha)$ is a crucial regulator of mitochondrial biogenesis. Replenishment with nicotinamide adenine dinucleotide (NAD) induces mitochondrial biogenesis by increasing PGC1 $\alpha$ expression $[18,19]$. NAM
Table 1 Production performance of broilers

\begin{tabular}{llllll}
\hline & $\mathrm{L}$ & $\mathrm{H}$ & COMB & SEM & $P$-value \\
\hline $\mathrm{Fl} / \mathrm{g}$ & 2843 & 2844 & 2844 & 27.8 & 1.000 \\
$\mathrm{BW} / \mathrm{g}$ & 2788 & 2745 & 2773 & 25.6 & 0.802 \\
$\mathrm{BWG} / \mathrm{g}$ & 1610 & 1533 & 1567 & 23.6 & 0.439 \\
$\mathrm{FCR}$ & 1.77 & 1.86 & 1.82 & 0.02 & 0.188 \\
\hline
\end{tabular}

Production performance included FI (feed intake), BW (body weight), BWG

(body weight gain) and FCR (feed conversion ratio)

is the primary source of NAD which is obtained through the salvage pathway. As a precursor of NAD, treatment with NAM also enhances PGC-1 $\alpha$ expression [20]. Impaired intramuscular NAD synthesis compromises skeletal muscle mass and strength over time, which can be quickly restored with an oral NAD precursor [21]. Besides, NAD biosynthesis alleviates muscular dystrophy in a zebrafish model [22] and promotes muscle function in Caenorhabditis elegans [23]. Addition of niacin (precursor of NAM) has been reported to increase the number of oxidative type I fibres in skeletal muscles of growing pigs [24] and induce type II to type I muscle fibre transition in sheep [25]. Further, supplementation with butyrate increases mitochondrial function and biogenesis of skeletal muscle in mice and rats [26, 27]. Further, the intake of BA increases the percentage of type 1 fibres $[26,28]$ and muscle fibre cross-sectional area in skeletal muscle [13].

Although supplementation with NAM or BA alone can elevate antioxidant capacity and improve the meat quality of broilers, the effect of combined supplementation with NAM and BA on the meat quality of broilers is not clear yet. Therefore, we performed transcriptome sequencing of broiler breast muscles to elucidate the molecular mechanism of the effect of feeding density and nutrient regulation on meat quality.

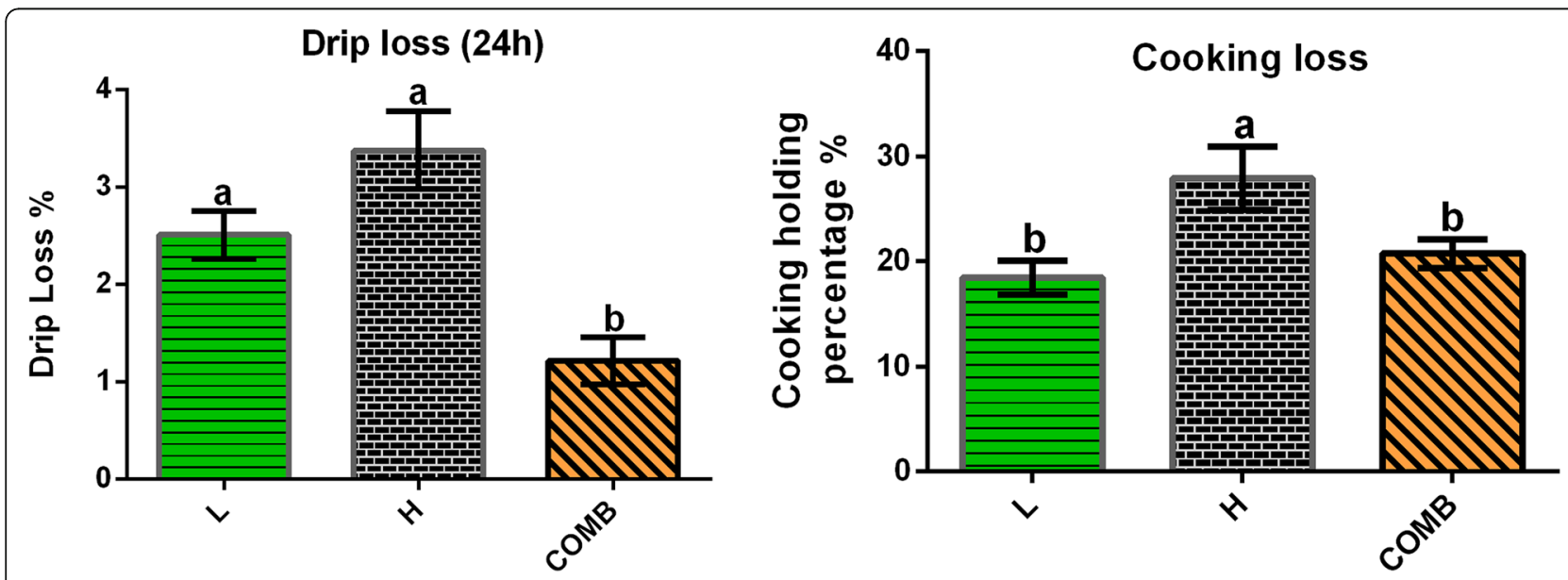

Fig. 1 Water holding capacity of breast muscle. Data are shown as the means \pm SEM. Different letters $a, b$ indicate that there are significant differences $(P<0.05)$ among these groups. L, low stocking density $\left(14\right.$ birds $\left./ \mathrm{m}^{2}\right)$; $\mathrm{H}$, high stocking density $\left(18\right.$ birds $\left./ \mathrm{m}^{2}\right)$; COMB, combination of NAM and BA (18 birds $\left./ \mathrm{m}^{2}\right)$ 

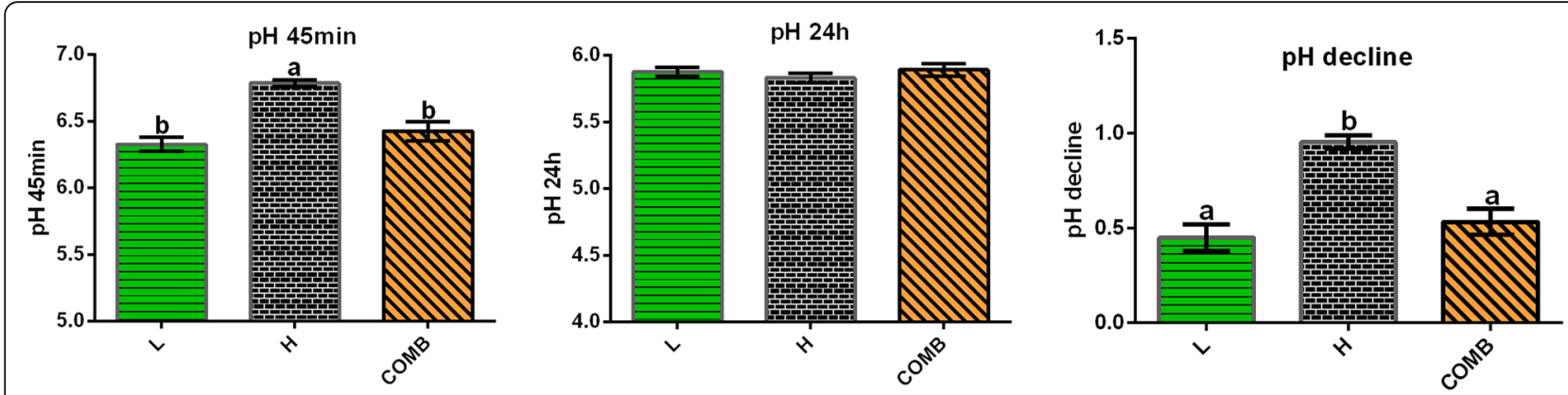

Fig. 2 The pH values of breast muscle. Data are shown as the means \pm SEM. Different letters $a, b$ indicate that there are significant differences $(P<0.05)$ among these groups. L, low stocking density $\left(14 \mathrm{birds} / \mathrm{m}^{2}\right) ; \mathrm{H}$, high stocking density $\left(18 \mathrm{birds} / \mathrm{m}^{2}\right)$; COMB, combination of NAM and BA $\left(18 \mathrm{birds} / \mathrm{m}^{2}\right)$

\section{Results}

Production performance and meat quality

There is no significant difference among the $\mathrm{H}, \mathrm{L}$ and COMB group in corresponding to FI, BW, BWG and FCR $(P>0.05)$ (Table 1$)$. Compared with the L group, the $\mathrm{H}$ group showed significantly increased cooking loss of breast muscle $(P<0.05)$. The COMB group showed decreased cooking loss compared with the $\mathrm{H}$ group $(P<$ 0.05). Besides, the drip loss in the COMB group was lower than that in the L group, as well $(P<0.05)$ (Fig. 1).

The 45-min $\mathrm{pH}$ value in the $\mathrm{H}$ group was higher than that in the other 2 groups $(P<0.05)$ while there was no significant difference in $24-\mathrm{h} \mathrm{pH}$ values among the groups. Thus, the $\mathrm{pH}$ decline during $45 \mathrm{~min}$ to $24 \mathrm{~h}$ in the $\mathrm{H}$ group was significantly higher than that in the other 2 groups, indicating that the $\mathrm{H}$ group had rapid $\mathrm{pH}$ drop rate, which was attenuated in the COMB group under high stocking density (Fig. 2).

\section{Anti-oxidant capacity}

The stocking density significantly altered the activity of LDH $(P=0.022)$. The activity of LDH in the $\mathrm{H}$ group was higher $(P<0.05)$ than that in the $\mathrm{L}$ group. The COMB group had significantly decreased $(P<0.05)$ activity of LDH when compared with the $\mathrm{H}$ group. However, stocking density had no significant effect on the activities of CK, T-AOC, MDH, anti-superoxide anion and the content of hydroxyproline (Table 2).

\section{RNA sequencing data and differentially expressed genes (DEGs)}

In the principal component analysis (PCA), there was a clear divergence among the $\mathrm{H}, \mathrm{L}$ and COMB groups. In the Venn diagram, the number of identified genes in the $\mathrm{H}, \mathrm{L}$ and COMB were $11,777,12,554$ and 11,633 , respectively (Fig. 3). Compared with the $\mathrm{H}$ group, the number of DEGs in the L group and COMB group were 3752 and 773, respectively (Fig. 4).

The gene sets were produced by DEGS. From Venn analysis of genes sets, we found that there were 1310 genes shared in common between the COMB group and the L group. Nevertheless, there were only 6 genes owed by both the COMB group and the $\mathrm{H}$ group. Similarly, from the iPath map of metabolic pathways, there were a total of 830 pathways annotated in common. In contrast, there was only 1 pathway owed by both the COMB group and the $\mathrm{H}$ group (Fig. 5).

\section{Up-regulated genes in the $\mathrm{H}$ group}

Compared with those in the L group, a total of 1894 genes were up-regulated in the $\mathrm{H}$ group (Fig. 4), which were mainly involved in muscle contraction, cell localization, ion transport, lipid metabolism, glycolysis, proteolysis, and immune stress (Fig. 6).

Muscle contraction-related pathways were enriched in the $\mathrm{H}$ group. They involved vital genes including MYLK2, NOS1, TMOD4, and Six1 (Table 3). The H group was enriched for cell-localization-related genes

Table 2 Enzyme activities of the breast muscle

\begin{tabular}{|c|c|c|c|c|c|}
\hline & $\mathrm{L}$ & $\mathrm{H}$ & $\mathrm{COMB}$ & SEM & $P$-value \\
\hline CK /U/mgprot & 2.51 & 2.41 & 2.25 & 0.12 & 0.702 \\
\hline LDH /U/gprot & $450.38^{a}$ & $724.10^{\mathrm{b}}$ & $383.22^{\mathrm{a}}$ & 56.74 & 0.022 \\
\hline T-AOC /U/mgprot & 100.81 & 82.17 & 86.01 & 8.25 & 0.650 \\
\hline $\mathrm{MDH} / \mathrm{U} / \mathrm{mgprot}$ & 1.37 & 1.21 & 1.53 & 0.08 & 0.252 \\
\hline Anti-superoxide anion /U/gprot & 10.30 & 9.32 & 10.39 & 0.39 & 0.489 \\
\hline Hydroxyproline / $/ \mu \mathrm{g} / \mathrm{mg}$ & 155.56 & 164.22 & 172.01 & 8.51 & 0.755 \\
\hline
\end{tabular}




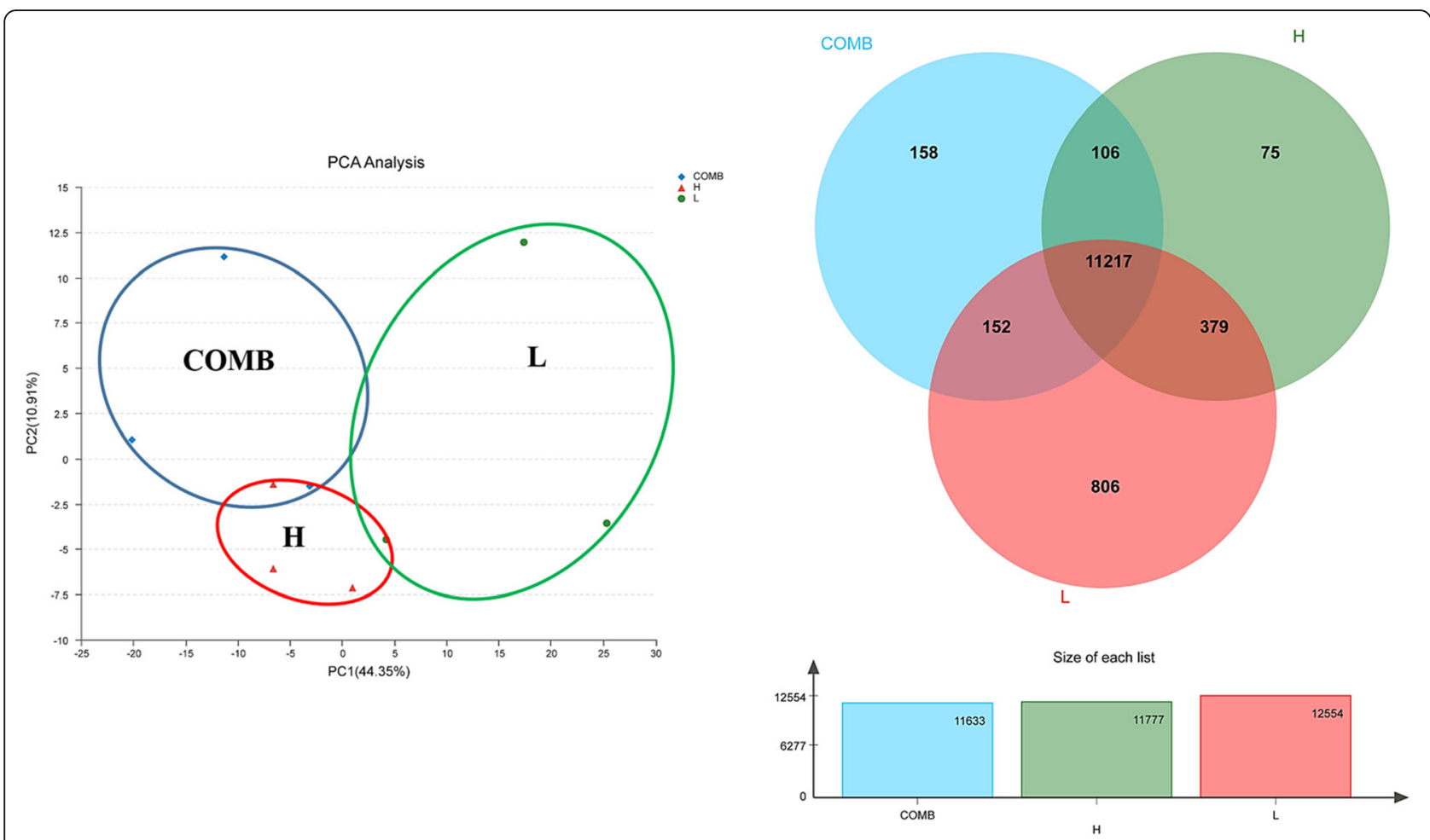

Fig. 3 Principal Component Analysis (PCA) and Wayne (VEEN) analysis of gene sets. For the PCA graph, the distance between each sample point represents the distance of the sample. The closer the distance means higher the similarity between samples; for the VEEN graph, the numbers inside the circle represents the sum of the number of expressed genes in the group. The crossover region represents the number of consensus expressed genes for each group

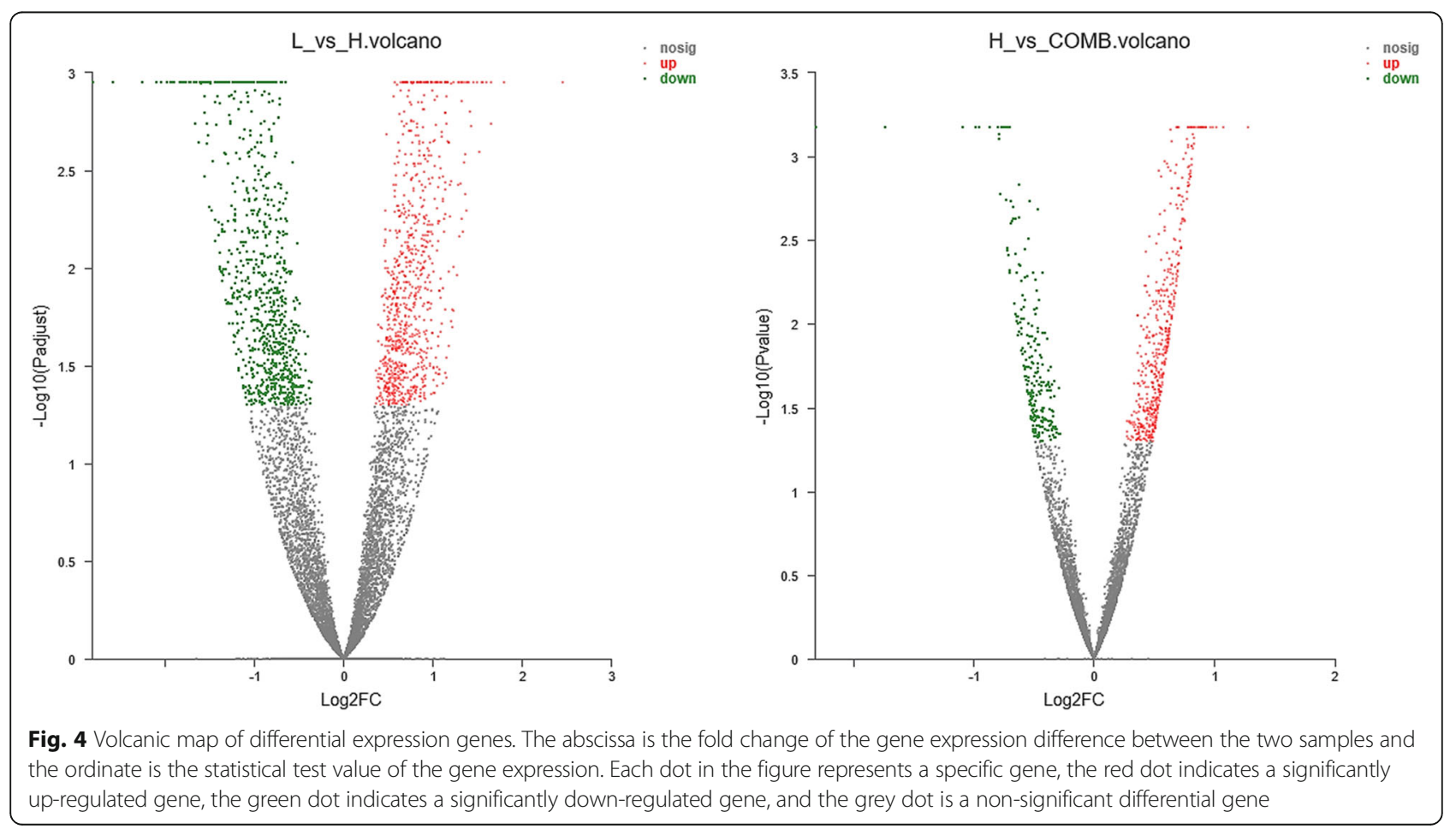


such as KEAP1, CDKN1A, ERBB4, and TMOD4 (Table 3). Additionally, high-density up-regulated ion and amino acid transport-related genes included $\mathrm{KCNJ} 12$, KCNA7, SLC38A3 and SLC38A4, which are involved in ion transmembrane transport and transporter activity (Table 4). High-density enriched glycolysis-related pathways included fructose metabolism, fructose-2,6-diphosphate 2-phosphatase activity, and fructose 2,6diphosphate metabolism (Table 5). The lipid metabolismrelated genes such as MID1IP1, ACACB and Lpin1 were up-regulated in $\mathrm{H}$ group, which are involved in lipid synthesis and lipid oxidation (Table 5).

Stress response pathways including non-biologically stimulated cellular responses, extracellular stimuli response and nutritional level response were also enriched in the $\mathrm{H}$ group. Furthermore, high-density up-regulated proteolysis-related genes include TINAG, USP24, OTUD1, KEAP1, KLHL34, and SMCR8. Also, high-density enriched immune pathways include the regulation of host defence responses to viruses and prostaglandin receptor-like binding (Table 6).

In Kyoto Encyclopedia of Genes and Genomes (KEGG) enrichment analysis, genes involved in calcium signalling pathway (RYR), inflammatory mediator regulation of RTP channels (PLA2) and chemokine signalling pathway (SOS) (Fig. S1, S2 and S3) were enriched in the $\mathrm{H}$ group.

\section{Down-regulated genes in the $\mathrm{H}$ group}

Compared with those in the L group, a total of 1858 genes were down-regulated in the $\mathrm{H}$ group (Fig. 4), which were involved in cell adhesion, cell matrix, and cell migration, etc. (Fig. 7).

The genes involved in muscle development include muscle fibre assembly and binding (LMOD2, MYOZ2 and ACTN1, etc.) and muscle fibre development (DSG2, LMOD2 and FSCN1, etc.), which were down-regulated

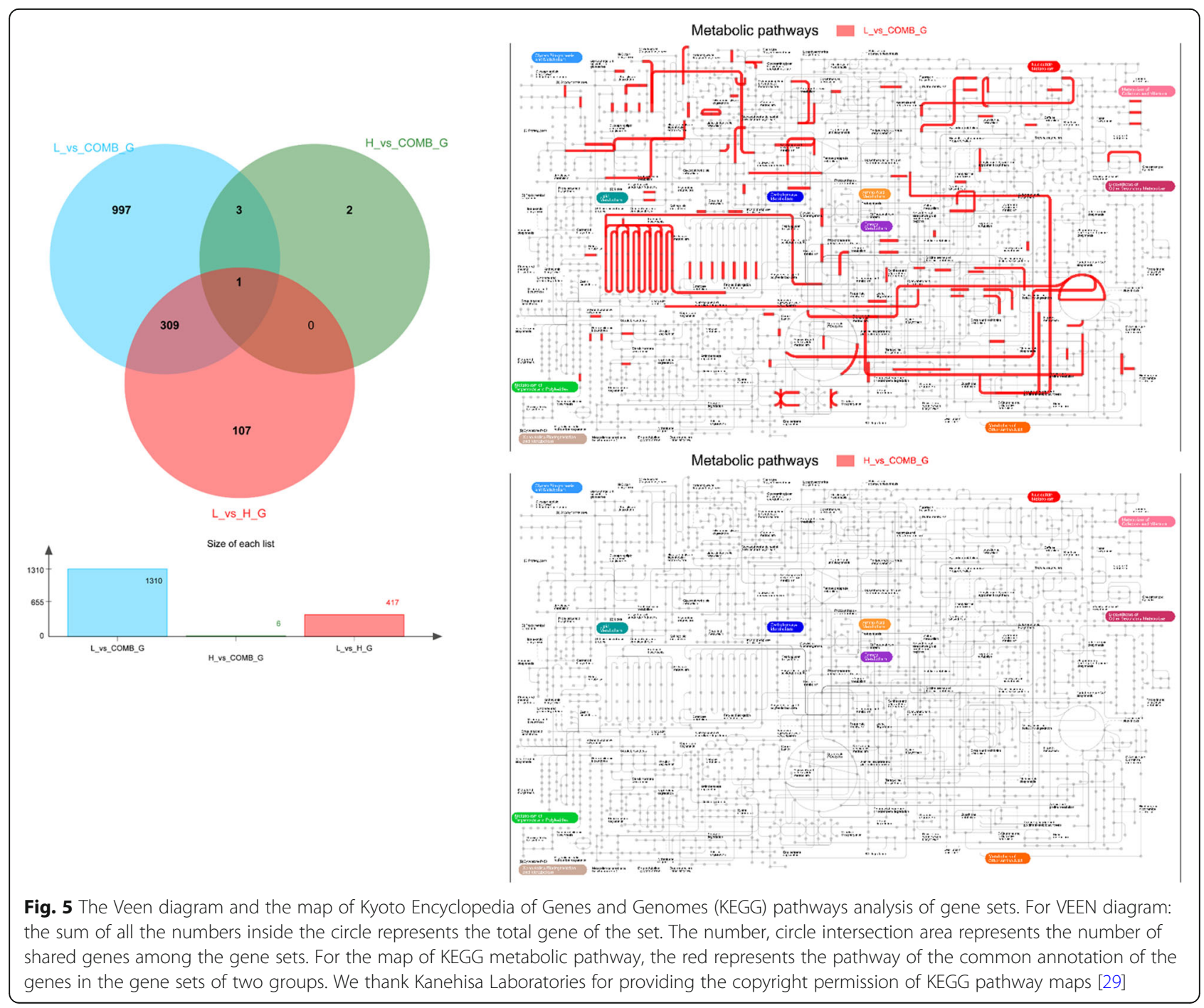




\section{GO enrichment analysis(H_L_up)}
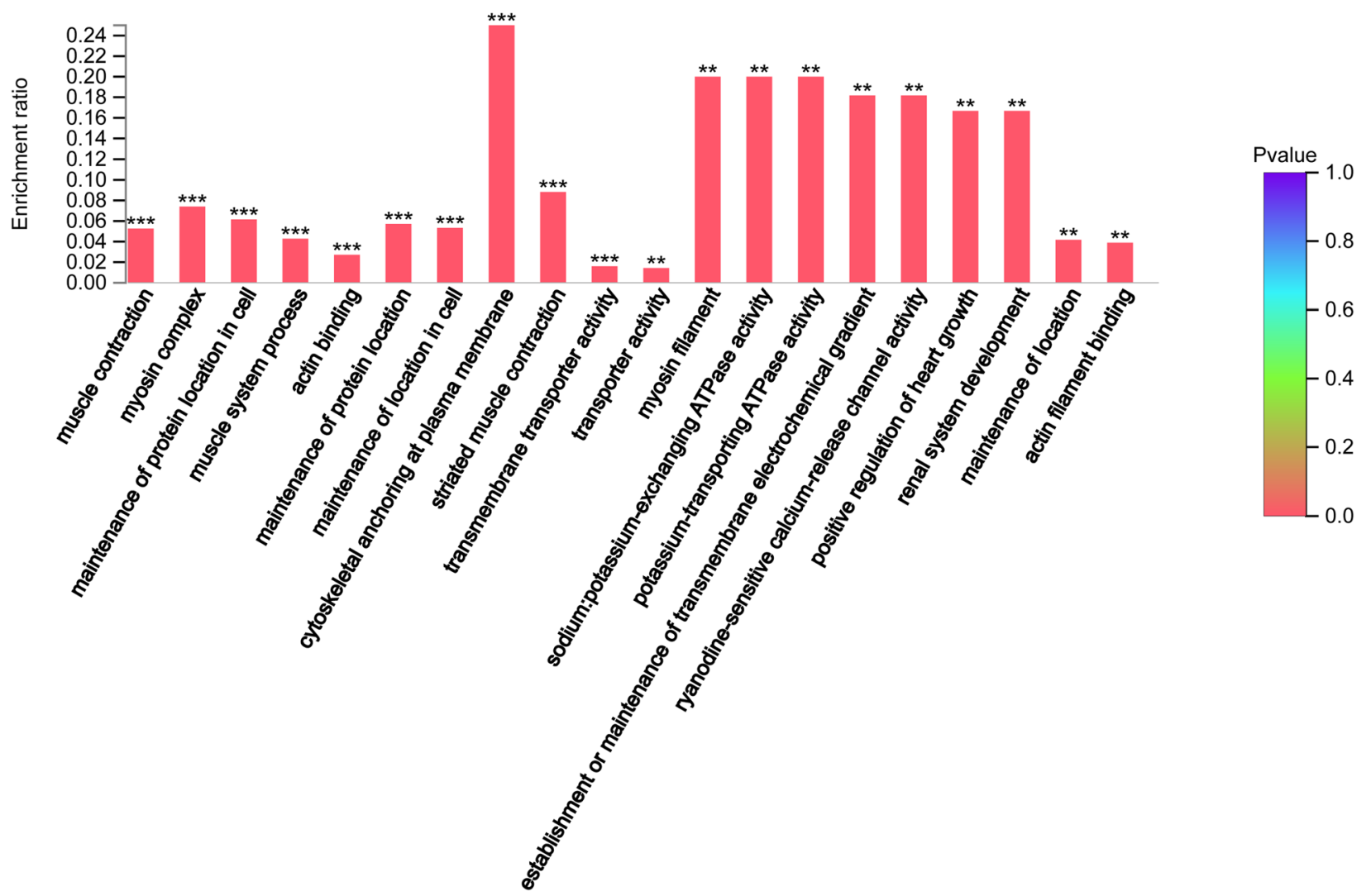

Fig. $6 \mathrm{GO}$ enrichment analysis of up-regulated genes in the $\mathrm{H}$ group. The abscissa indicates the $\mathrm{GO}$ term, and the ordinate indicates the enrichment ratio. "**"means $P<0.05$, "***"means $P<0.01$ and "***" means $P<0.001$

in $\mathrm{H}$ group (Table 7). High-density also down-regulated genes related to cell-matrix pathways such as MMP9, FBLN1, THBS4, and VCAN. High-density also downregulated collagen synthesis and collagen binding related genes including ADAMTS3, ADAMTS14, COL1A2, and LUM (Table 8). Besides, the adhesion-associated genes including DSG2, CSTA, THY1, TGFBI, NOV, CDH11 and FN1 were diminished. Additionally, antioxidant genes including MGST2, PTGS2, NCF1, SOD3, and CYBB were also down-regulated (Table 9).

In KEGG enrichment analysis, down-regulated genes in the $\mathrm{H}$ group were involved in ECM-receptor interaction (COL1A, THBS1, FN1, TN, ITGA5, ITGA8 and ITGB8), adherens junction (SHP-1, TGF $\beta$ R, $\alpha$-Actinin and Slug) and focal adhesion (Actinin and MLC) (Fig. S4, S5 and S6).

\section{Up-regulated genes in the COMB group}

Compared with those in the $\mathrm{H}$ group, up-regulated genes in the COMB group were involved in muscle development, hyaluronic acid synthesis, mitochondrial function, and redox pathway (Fig. 8).

The muscle development-related pathways enriched in the COMB group included positive regulation of muscle tissue development and muscle cell decision processes, which involved key genes such as MYF6, LMCD1 and TRPC3. Besides, the COMB group was enriched for mitochondria-associated pathways such as electron transport chains, mitochondrial respiratory chain complex I and mitochondrial protein complex pathways, which involved genes including TOMM6, NDUFV1, NDUFS5, NDUFB2, NDUFA2, LMCD1, ZNF593 and COASY (Table 10). The hyaluronic acid-related genes upregulated in the COMB group included HYAL1 and HYAL3. Besides, the redox-related genes including LDHD, CPOX, SUOX, NDUFV1, GRHPR, DOHH and NDUFA2 were up-regulated in the COMB group, which were involved in the pathways such as redox process, NAD binding, NADPH binding and NADH dehydrogenase complex (Table 11). In KEGG enrichment analysis, up-regulated genes in the COMB group were involved in 
Table 3 Muscle contraction and cell location related pathways

\begin{tabular}{|c|c|c|c|c|}
\hline GO ID & Term Type & Description & $\boldsymbol{P}$-value & Genes \\
\hline \multicolumn{5}{|c|}{ Muscle contraction related pathways } \\
\hline GO:0044449 & $\mathrm{CC}$ & contractile fiber part & 0.026498 & NOS1; TMOD4 \\
\hline GO:0006936 & $\mathrm{BP}$ & muscle contraction & 0.000194 & MYLK2; NOS1 \\
\hline GO:0006941 & $\mathrm{BP}$ & striated muscle contraction & 0.000908 & MYLK2; NOS1 \\
\hline GO:0003012 & $\mathrm{BP}$ & muscle system process & 0.00051 & MYLK2; NOS1 \\
\hline GO:0051015 & MF & actin filament binding & 0.002704 & TMOD4 \\
\hline GO:0003779 & MF & actin binding & 0.000614 & TMOD4 \\
\hline GO:0008092 & MF & cytoskeletal protein binding & 0.033316 & TMOD4 \\
\hline GO:0004687 & MF & myosin light chain kinase activity & 0.022364 & MYLK2 \\
\hline \multicolumn{5}{|c|}{ Cell location related pathways } \\
\hline GO:0051235 & $\mathrm{BP}$ & maintenance of location & 0.002093 & KEAP1 \\
\hline GO:0051651 & $\mathrm{BP}$ & maintenance of location in cell & 0.000837 & KEAP1 \\
\hline GO:0045185 & $\mathrm{BP}$ & maintenance of protein location & 0.000645 & KEAP1 \\
\hline GO:0032507 & $\mathrm{BP}$ & maintenance of protein location in cell & 0.000486 & KEAP1 \\
\hline GO:1900180 & $\mathrm{BP}$ & regulation of protein localization to nucleus & 0.032179 & KEAP1; CDKN1A; ERBB4 \\
\hline GO:2000010 & $\mathrm{BP}$ & positive regulation of protein localization to cell surface & 0.044234 & ERBB4 \\
\hline GO:0042306 & $\mathrm{BP}$ & regulation of protein import into nucleus & 0.018345 & KEAP1; CDKN1A; ERBB4 \\
\hline GO:1904589 & $\mathrm{BP}$ & regulation of protein import & 0.018837 & KEAP1; CDKN1A; ERBB4 \\
\hline
\end{tabular}

Table 4 lon transport related pathways

\begin{tabular}{|c|c|c|c|c|}
\hline GO ID & Term Type & Description & $\boldsymbol{P}$-value & Genes \\
\hline \multicolumn{5}{|c|}{ Ion transport related pathways } \\
\hline GO:0030001 & $\mathrm{BP}$ & metal ion transport & 0.015075 & KCNJ12 \\
\hline GO:0002028 & $\mathrm{BP}$ & regulation of sodium ion transport & 0.017458 & NOS1 \\
\hline GO:0051365 & $\mathrm{BP}$ & cellular response to potassium ion starvation & 0.011244 & SLC38A3 \\
\hline GO:0006813 & $\mathrm{BP}$ & potassium ion transport & 0.030866 & KCNJ12 \\
\hline GO:0034220 & $\mathrm{BP}$ & ion transmembrane transport & 0.015681 & SLC38A4; SLC38A3; KCNJ12 \\
\hline GO:0010107 & $\mathrm{BP}$ & potassium ion import & 0.004526 & KCNJ12 \\
\hline GO:0006813 & $\mathrm{BP}$ & potassium ion transport & 0.030866 & KCNJ12 \\
\hline GO:0098655 & $\mathrm{BP}$ & cation transmembrane transport & 0.024337 & SLC38A3; KCNJ12 \\
\hline GO:0006812 & $\mathrm{BP}$ & cation transport & 0.027707 & SLC38A3; KCNJ12 \\
\hline GO:0098662 & $\mathrm{BP}$ & inorganic cation transmembrane transport & 0.046453 & KCNJ12 \\
\hline GO:0015075 & MF & ion transmembrane transporter activity & 0.008902 & KCNA7; SLC38A4; SLC38A3 \\
\hline GO:0046873 & MF & metal ion transmembrane transporter activity & 0.007993 & KCNJ12 \\
\hline GO:0008324 & MF & cation transmembrane transporter activity & 0.01451 & SLC38A3; KCNJ12 \\
\hline GO:0022890 & MF & inorganic cation transmembrane transporter activity & 0.022537 & KCNJ12 \\
\hline GO:0005261 & MF & cation channel activity & 0.045897 & KCNJ12 \\
\hline GO:0005216 & MF & ion channel activity & 0.03925 & KCNA7; KCNJ12 \\
\hline GO:0015276 & MF & ligand-gated ion channel activity & 0.026498 & KCNJ12 \\
\hline GO:0015079 & MF & potassium ion transmembrane transporter activity & 0.029581 & KCNJ12 \\
\hline
\end{tabular}


Table 5 Glycolysis and lipid metabolism related pathways

\begin{tabular}{|c|c|c|c|c|}
\hline GO ID & Term Type & Description & $P$-value & Genes \\
\hline \multicolumn{5}{|c|}{ Glycolysis related pathways } \\
\hline GO:0006000 & $\mathrm{BP}$ & fructose metabolic process & 0.038812 & PFKFB1 \\
\hline GO:0004331 & MF & fructose-2,6-bisphosphate 2-phosphatase activity & 0.01682 & PFKFB1 \\
\hline GO:0003873 & MF & 6-phosphofructo-2-kinase activity & 0.022364 & PFKFB1 \\
\hline GO:0050308 & MF & sugar-phosphatase activity & 0.038812 & PFKFB1 \\
\hline GO:0008443 & MF & phosphofructokinase activity & 0.038812 & PFKFB1 \\
\hline GO:0006003 & $\mathrm{BP}$ & fructose 2,6-bisphosphate metabolic process & 0.022364 & PFKFB1 \\
\hline \multicolumn{5}{|c|}{ Lipid metabolism related pathways } \\
\hline GO:0003989 & MF & acetyl-CoA carboxylase activity & 0.044234 & $A C A C B$ \\
\hline GO:0019217 & $\mathrm{BP}$ & regulation of fatty acid metabolic process & 0.016548 & MID1IP1; ACACB \\
\hline GO:0046949 & $\mathrm{BP}$ & fatty-acyl-CoA biosynthetic process & 0.03336 & $A C A C B$ \\
\hline GO:0019432 & $\mathrm{BP}$ & triglyceride biosynthetic process & 0.03336 & Lpin1 \\
\hline GO:0046463 & $\mathrm{BP}$ & acylglycerol biosynthetic process & 0.038812 & Lpin1 \\
\hline GO:0046460 & $\mathrm{BP}$ & neutral lipid biosynthetic process & 0.038812 & Lpin1 \\
\hline GO:0046322 & $\mathrm{BP}$ & negative regulation of fatty acid oxidation & 0.01682 & $A C A C B$ \\
\hline GO:0031998 & $\mathrm{BP}$ & regulation of fatty acid beta-oxidation & 0.044234 & $A C A C B$ \\
\hline GO:0031999 & $\mathrm{BP}$ & negative regulation of fatty acid beta-oxidation & 0.011244 & $A C A C B$ \\
\hline GO:0045723 & $\mathrm{BP}$ & positive regulation of fatty acid biosynthetic process & 0.027877 & MID1IP1 \\
\hline GO:0010884 & $\mathrm{BP}$ & positive regulation of lipid storage & 0.044234 & $A C A C B$ \\
\hline GO:2001295 & $\mathrm{BP}$ & malonyl-CoA biosynthetic process & 0.011244 & $\mathrm{ACACB}$ \\
\hline GO:2001293 & $\mathrm{BP}$ & malonyl-CoA metabolic process & 0.01682 & $A C A C B$ \\
\hline GO:0010565 & $\mathrm{BP}$ & regulation of cellular ketone metabolic process & 0.047727 & MID1IP1; ACACB \\
\hline
\end{tabular}

Table 6 Proteolysis, immune and stress related pathways

\begin{tabular}{|c|c|c|c|c|}
\hline GO ID & Term Type & Description & $P$-value & Genes \\
\hline \multicolumn{5}{|c|}{ Proteolysis related pathways } \\
\hline GO:0008234 & MF & cysteine-type peptidase activity & 0.032179 & TINAG; USP24; OTUD1 \\
\hline GO:0031463 & $\mathrm{CC}$ & Cul3-RING ubiquitin ligase complex & 0.028791 & KEAP1; KLHL34 \\
\hline GO:0010499 & $\mathrm{BP}$ & proteasomal ubiquitin-independent protein catabolic process & 0.03336 & KEAP1 \\
\hline GO:0010508 & $\mathrm{BP}$ & positive regulation of autophagy & 0.034688 & SMCR8 \\
\hline GO:1902902 & $\mathrm{BP}$ & negative regulation of autophagosome assembly & 0.03336 & SMCR8 \\
\hline GO:1901096 & $\mathrm{BP}$ & regulation of autophagosome maturation & 0.011244 & SMCR8 \\
\hline GO:1901098 & $\mathrm{BP}$ & positive regulation of autophagosome maturation & 0.011244 & SMCR8 \\
\hline \multicolumn{5}{|c|}{ Immune and stress related pathways } \\
\hline GO:0031867 & MF & EP4 subtype prostaglandin E2 receptor binding & 0.005638 & FEM1A \\
\hline GO:0031862 & MF & prostanoid receptor binding & 0.005638 & FEM1A \\
\hline GO:0050691 & $\mathrm{BP}$ & regulation of defense response to virus by host & 0.031097 & ALKBH5; ALPK1 \\
\hline GO:0002230 & $\mathrm{BP}$ & positive regulation of defense response to virus by host & 0.026558 & ALKBH5; ALPK1 \\
\hline GO:0071214 & $\mathrm{BP}$ & cellular response to abiotic stimulus & 0.042948 & CDKN1A; SLC38A3 \\
\hline GO:0009991 & $\mathrm{BP}$ & response to extracellular stimulus & 0.022488 & ACACB; CDKN1A; SLC38A3 \\
\hline GO:0031667 & $\mathrm{BP}$ & response to nutrient levels & 0.018345 & ACACB; CDKN1A; SLC38A3 \\
\hline
\end{tabular}




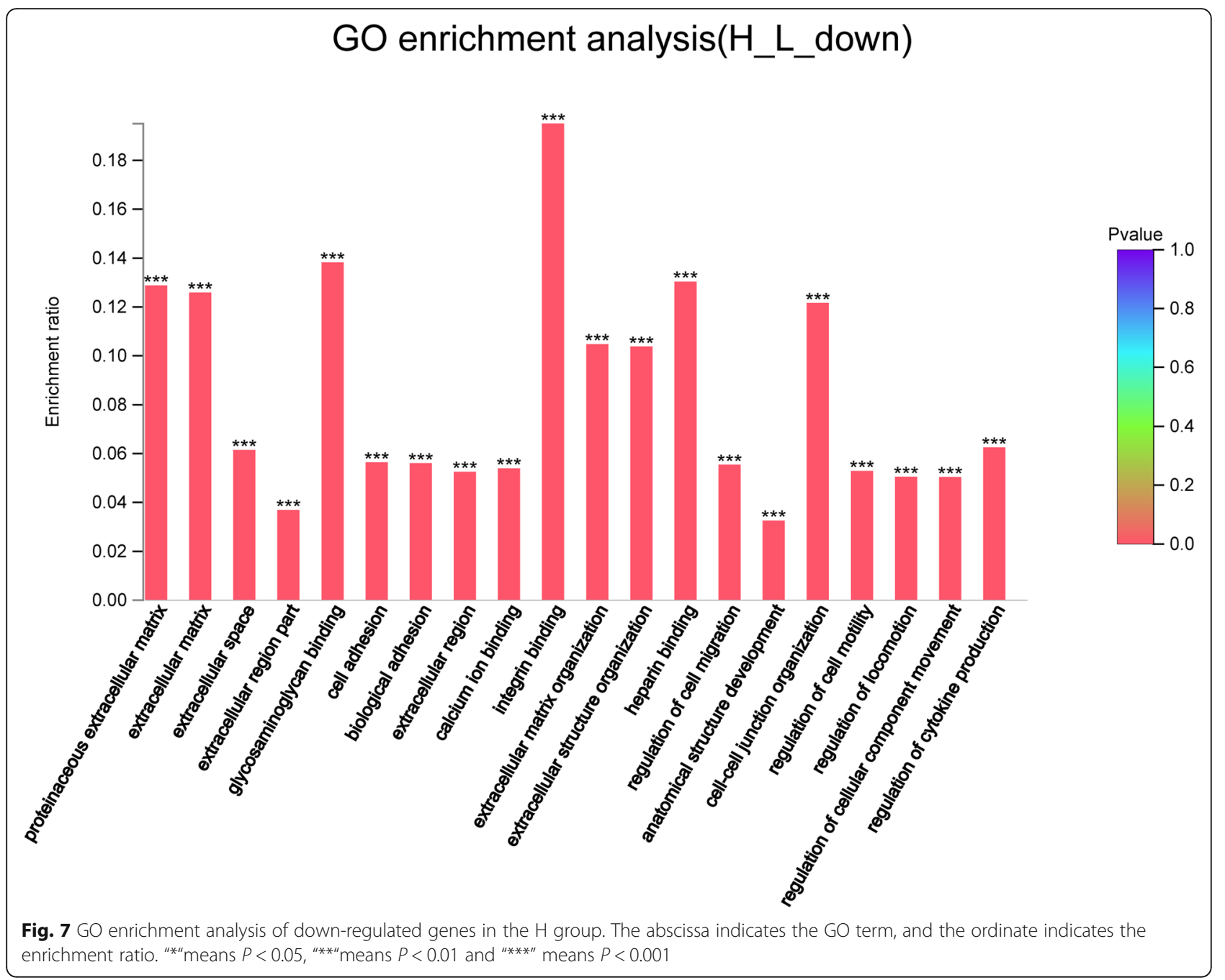

oxidative phosphorylation (NDUFS5, NDUFV1, NDUFA2, NDUFA13, NDUFB2, NDUFB7 and NDUFC2) (Fig. S7).

\section{Down-regulated genes in the COMB group}

Compared with those in the $\mathrm{H}$ group, down-regulated genes in the COMB group were involved in the inflammatory response, acid metabolism, fatty acid metabolism, and glycolysis-related pathways (Fig. 9).

The inflammatory response-related genes downregulated in the COMB group included CCR5 and ALOX5 while the immune response-related genes included C1S, BLK, CCR5 and MARCH1 (Table 12). The acid metabolism-related pathways include organic acid synthesis process, oxoacid metabolism process and carboxylic acid synthesis process, which involved genes such as PSAT1, SCD, MAT1A, ALOX5, ST3GAL1 and ALDOB. The genes involved in fatty acid metabolism pathways include SCD and ALOX5. In addition, downregulated genes in the $\mathrm{COMB}$ group were involved in glycolytic and carbohydrate metabolism, which included GALNT16, ST3GAL1, ALDOB and MAT1A (Table 13).

In KEGG enrichment analysis, genes involved in the regulation of lipolysis in adipocytes (PLIN), glycolysis/ gluconeogenesis (ALDO) and arachidonic acid metabolism (ALOX5) were down-regulated in the COMB group (Fig. S8, S9 and S10).

\section{Transcriptome differential gene verification}

The transcriptome differential genes were verified by real-time PCR, and the gene expression pattern was consistent with the transcriptome results (Fig. 10).

\section{Discussion}

In the current study, the $\mathrm{H}$ group showed significantly increased cooking loss of breast muscle when compared with the L group. The muscle disease such as PSE (Pale, Soft and Exudative) meat [30] and wooden breast [31] have higher cooking loss than normal meat. 
Table 7 Muscle development related pathway

\begin{tabular}{|c|c|c|c|c|}
\hline GO ID & $\begin{array}{l}\text { Term } \\
\text { Type }\end{array}$ & Description & $\boldsymbol{P}$-value & Genes \\
\hline \multicolumn{5}{|c|}{ Muscle development related pathways } \\
\hline $\begin{array}{l}\text { GO: } \\
0030239\end{array}$ & $\mathrm{BP}$ & myofibril assembly & 0.021003 & LMOD2; MYOZ2 \\
\hline $\begin{array}{l}\text { GO: } \\
0043205\end{array}$ & $\mathrm{CC}$ & fibril & 0.008763 & FN1; LTBP1 \\
\hline $\begin{array}{l}\text { GO: } \\
0045214\end{array}$ & $\mathrm{BP}$ & sarcomere organization & 0.045011 & LMOD2; ACTN1 \\
\hline $\begin{array}{l}\text { GO: } \\
0051017\end{array}$ & $\mathrm{BP}$ & actin filament bundle assembly & $9.31 \mathrm{E}-05$ & LIMA1; ACTN1; DPYSL3; FSCN1 \\
\hline $\begin{array}{l}\text { GO: } \\
0061572\end{array}$ & $\mathrm{BP}$ & actin filament bundle organization & 0.00013 & LIMA1; ACTN1; DPYSL3; FSCN1 \\
\hline $\begin{array}{l}\text { GO: } \\
0007015\end{array}$ & $\mathrm{BP}$ & actin filament organization & 0.001785 & LIMA1; LMOD2; ACTN1; DPYSL3; FSCN1 \\
\hline $\begin{array}{l}\text { GO: } \\
0030036\end{array}$ & $\mathrm{BP}$ & actin cytoskeleton organization & 0.002238 & $\begin{array}{l}\text { LMOD2; MYOZ2; Fgf7; ACTN1; MYL6; CNN2; DOCK2; } \\
\text { FSCN1 }\end{array}$ \\
\hline $\begin{array}{l}\text { GO: } \\
0031032\end{array}$ & $\mathrm{BP}$ & actomyosin structure organization & 0.001641 & LMOD2; MYOZ2; ACTN1; MYL6; CNN2 \\
\hline $\begin{array}{l}\text { GO: } \\
0003779\end{array}$ & MF & actin binding & 0.000306 & $\begin{array}{l}\text { MYH15; LIMA1; LMOD2; MYOZ2; ACTN1; MYL6; CNN2; } \\
\text { MYL3; FSCN1 }\end{array}$ \\
\hline $\begin{array}{l}\text { GO: } \\
0005523\end{array}$ & MF & tropomyosin binding & 0.006889 & LMOD2; S100A6 \\
\hline $\begin{array}{l}\text { GO: } \\
0070051\end{array}$ & MF & fibrinogen binding & 0.016237 & FBLN1 \\
\hline $\begin{array}{l}\text { GO: } \\
0050436\end{array}$ & MF & microfibril binding & 0.032211 & LTBP1 \\
\hline $\begin{array}{l}\text { GO: } \\
0060537\end{array}$ & $\mathrm{BP}$ & muscle tissue development & 0.029507 & DSG2; EYA2; BMP5; ITGA8 \\
\hline $\begin{array}{l}\text { GO: } \\
0032970\end{array}$ & $\mathrm{BP}$ & regulation of actin filament-based process & 0.033864 & DSG2; LIMA1; LMOD2; WNT11; SERPINF2; FSCN1; F2RL1 \\
\hline $\begin{array}{l}\text { GO: } \\
0030029\end{array}$ & $\mathrm{BP}$ & actin filament-based process & 0.003744 & $\begin{array}{l}\text { LMOD2; MYOZ2; Fgf7; ACTN1; MYL6; CNN2; DOCK2; } \\
\text { FSCN1 }\end{array}$ \\
\hline $\begin{array}{l}\text { GO: } \\
0014883\end{array}$ & $\mathrm{BP}$ & transition between fast and slow fiber & 0.047928 & TNNI1 \\
\hline $\begin{array}{l}\text { GO: } \\
1902724\end{array}$ & $\mathrm{BP}$ & $\begin{array}{l}\text { positive regulation of skeletal muscle satellite cell } \\
\text { proliferation }\end{array}$ & 0.047928 & HGF \\
\hline
\end{tabular}

Stress is an essential cause of the decline in meat quality. In this study, the activity of LDH in the $\mathrm{H}$ group was higher than that in the L group. In transcriptome analysis, the enriched genes in the $\mathrm{H}$ group were involved in stimuli response pathway. In the $\mathrm{H}$ group, genes encoding nitric oxide synthase 1 (NOS1), Kelch-Like ECHassociated protein 1 (KEAP1) and cyclin-dependent kinase inhibitor 1A (p21, Cip1) (CDKN1A) were upregulated. High levels of NO reduce the antioxidant capacity of post-mortem muscles, increasing the accumulation of ROS and reactive nitrogen, resulting in high levels of protein oxidation. Studies have shown that inhibition of nitric oxide synthase can significantly reduce protein carbonyl content and protein oxidation [32]. Inhibition of CDKN1A expression by miRNAs promotes myoblast proliferation [33]. Up-regulation of KEAP1 expression increases the degradation of Nrf2 in cells, making cells more susceptible to free radical damage [34]. Heat stress can reduce the oxidative stability of broiler muscle protein and reduce the strength of the myofibrillar gel, resulting in increased drip loss and cooking loss in broilers [35]. A study has shown that genes involved in the stimulation response pathway are significantly enriched in muscles with high drip loss [36]. Therefore, increased expression of stress pathwayrelated genes such as KEAP1 and CDKN1A may be one of the causes of muscle quality deterioration.

This study found that the $\mathrm{H}$ group had the fastest $\mathrm{pH}$ decline rate. The rapid decline in $\mathrm{pH}$ is usually accompanied by an increase in the rate of glycolysis and the accumulation of lactic acid, resulting in a decrease of muscle function [37]. In this study, high stocking density 
Table 8 Cellular matrix and collagen related pathway

\begin{tabular}{|c|c|c|c|c|}
\hline GO ID & Term Type & Description & $P$-value & Genes \\
\hline \multicolumn{5}{|c|}{ Cellular matrix related pathways } \\
\hline GO:0030198 & $\mathrm{BP}$ & extracellular matrix organization & $1.05 E-06$ & MMP9; TGFBI; ABI3BP; POSTN; FBLN1, etc \\
\hline GO:0044420 & CC & extracellular matrix component & 2.83E-05 & COL1A2; FN1; THBS2; THBS4; LTBP1, etc \\
\hline GO:0005578 & $\mathrm{CC}$ & proteinaceous extracellular matrix & $1.71 \mathrm{E}-11$ & FN1; THBS2; ADAMTS3; ADAMTS14; COL12A1, etc \\
\hline GO:0005614 & $\mathrm{CC}$ & interstitial matrix & 0.013106 & FN1; ABI3BP \\
\hline GO:0043062 & $\mathrm{BP}$ & extracellular structure organization & 1.15E-06 & MMP9; TGFBI; ABI3BP; ADAMTS14; POSTN, etC \\
\hline GO:0005201 & MF & extracellular matrix structural constituent & 0.017449 & MGP; VCAN; FBLN1 \\
\hline GO:0031232 & $\mathrm{CC}$ & extrinsic component of external side of plasma membrane & 0.032211 & SERPINE2 \\
\hline GO:0019897 & $\mathrm{CC}$ & extrinsic component of plasma membrane & 0.000874 & SERPINE2; S100A6; RGS1; KCNAB1 \\
\hline GO:1990430 & MF & extracellular matrix protein binding & 0.047928 & ITGB8 \\
\hline \multicolumn{5}{|c|}{ Collagen related pathways } \\
\hline GO:0032964 & $\mathrm{BP}$ & collagen biosynthetic process & 0.047928 & ADAMTS3 \\
\hline GO:0032963 & $\mathrm{BP}$ & collagen metabolic process & 0.027114 & MMP9; ADAMTS3 \\
\hline GO:0010712 & $\mathrm{BP}$ & regulation of collagen metabolic process & 0.023978 & SERPINF2; FAP \\
\hline GO:0010710 & $\mathrm{BP}$ & regulation of collagen catabolic process & 0.032211 & FAP \\
\hline GO:0030199 & $\mathrm{BP}$ & collagen fibril organization & 0.000216 & ADAMTS14; SFRP2; LUM; SERPINF2 \\
\hline GO:0005518 & MF & collagen binding & 0.00265 & TGFBI; ABI3BP; COMP; LUM \\
\hline GO:0005540 & MF & hyaluronic acid binding & 0.037432 & TNFAIP6; VCAN \\
\hline GO:0005581 & $\mathrm{CC}$ & collagen trimer & 0.000699 & COL1A2; COL12A1; COLEC12; LUM; COL14A1 \\
\hline GO:0005583 & CC & fibrillar collagen trimer & 0.001541 & COL1A2; LUM \\
\hline GO:0005539 & MF & glycosaminoglycan binding & 3.59E-09 & MDK; SLIT3; NOV; SERPINE2; JCHAIN, etC \\
\hline GO:1901617 & $\mathrm{BP}$ & organic hydroxy compound biosynthetic process & 0.033592 & NR4A2; PLTP; LCAT; AKR1D1 \\
\hline
\end{tabular}

led to up-regulation of genes involved in glycolysis and fat metabolism pathways. Anaerobic glycolysis is a vital energy metabolism pathway for post-mortem broilers. Under anaerobic conditions, muscle glycogen degradation occurs through glycolysis, which causes pyruvate to synthesize lactic acid, thus leading to a decrease in muscle $\mathrm{pH}$ due to the accumulation of lactic acid [38, 39]. High stocking density in this study also caused upregulation of striated muscle contraction pathwayrelated genes such as SIX homeobox 1 (Six1). It has been found that white streak muscles have up-regulated expression of striated muscle contraction-related genes compared with normal meat [40]. Six1 converts slow muscle fibres into fast muscle fibres $[41,42]$. The proportion of fast muscle fibres was negatively correlated with post-mortem $\mathrm{pH}$ [43]. Besides, the enriched genes in the $\mathrm{H}$ group were involved in calcium transport, sodium transport, and cation transport. Importantly, ion balance is the basis for maintaining normal physiological functions. Abnormal metabolism caused by high concentrations of calcium ions may be associated with the incidence of turkey PSE [44]. Furthermore, changes in muscle cation homeostasis may mark the beginning of muscle degeneration [45] and cause a reduction in meat quality [46].

Dietary supplementation with niacin (nicotinamide precursor) at $60 \mathrm{mg} / \mathrm{kg}$ was reported to reduce the drip loss of breast muscles in broilers [14]. In our study, the COMB group showed significantly reduced drip loss and cooking loss compared with the $\mathrm{H}$ group. Further, the COMB group showed significantly decreased activity of $\mathrm{LDH}$ compared to the $\mathrm{H}$ group. Besides, the COMB group showed inhibited expression of glycolytic and inflammation genes [37].

In KEGG enrichment analysis, the enriched genes in the $\mathrm{H}$ group were involved in inflammatory mediator regulation of RTP channels and chemokine signalling pathway. In contrast, the up-regulated genes in the COMB group were involved in the inflammatory response. Macrophage infiltration in the pectoral muscle might cause muscle damage [47]. The muscle disease such as white striped muscle is usually accompanied by elevated expression of immune-related genes [40]. During tissue degeneration, immune cells immediately enter the site of injury, triggering an inflammatory response, and attracting more immune cells to the damaged area. 
Table 9 Cell adhesion and antioxidant related pathway

\begin{tabular}{|c|c|c|c|c|}
\hline GO ID & $\begin{array}{l}\text { Term } \\
\text { Type }\end{array}$ & Description & $P$-value & Genes \\
\hline \multicolumn{5}{|c|}{ Cell adhesion related pathways } \\
\hline $\begin{array}{l}\text { GO: } \\
0007155\end{array}$ & $\mathrm{BP}$ & cell adhesion & 3.1E-08 & DSG2; TGFBI; NOV; FN1; THBS2; COMP, etc \\
\hline $\begin{array}{l}\text { GO: } \\
0098609\end{array}$ & $\mathrm{BP}$ & cell-cell adhesion & 0.030671 & DSG2; CSTA; NOV; CDH11; THBS4; BMP5, etc \\
\hline $\begin{array}{l}\text { GO: } \\
0007160\end{array}$ & $\mathrm{BP}$ & cell-matrix adhesion & 0.02187 & FN1; ITGB8; ITGA8 \\
\hline $\begin{array}{l}\text { GO: } \\
0050839\end{array}$ & MF & cell adhesion molecule binding & 0.000141 & DSG2; THY1; TGFBI; NOV; FN1; THBS4, etc \\
\hline $\begin{array}{l}\text { GO: } \\
0005911\end{array}$ & $\mathrm{CC}$ & cell-cell junction & 0.001091 & $\begin{array}{l}\text { DSG2; CD3E; GJA1; NOV; ABCB11; ACTN1, } \\
\text { etc }\end{array}$ \\
\hline $\begin{array}{l}\text { GO: } \\
0007045\end{array}$ & $\mathrm{BP}$ & cell-substrate adherens junction assembly & 0.010838 & THY1; FN1 \\
\hline $\begin{array}{l}\text { GO: } \\
0045216\end{array}$ & $\mathrm{BP}$ & cell-cell junction organization & $2.94 \mathrm{E}-06$ & DSG2; THY1; GJA1; FN1; WNT11; FSCN1 \\
\hline $\begin{array}{l}\text { GO: } \\
0007043\end{array}$ & $\mathrm{BP}$ & cell-cell junction assembly & 0.028627 & WNT11; FSCN1 \\
\hline $\begin{array}{l}\text { GO: } \\
0034332\end{array}$ & $\mathrm{BP}$ & adherens junction organization & 0.048995 & THY1; FN1 \\
\hline $\begin{array}{l}\text { GO: } \\
0034329\end{array}$ & $\mathrm{BP}$ & cell junction assembly & 0.002273 & THY1; FN1; WNT11; FSCN1 \\
\hline $\begin{array}{l}\text { GO: } \\
0010811\end{array}$ & $\mathrm{BP}$ & positive regulation of cell-substrate adhesion & 0.00285 & THY1; FN1; ABI3BP; EDIL3; FBLN1 \\
\hline $\begin{array}{l}\text { GO: } \\
0034333\end{array}$ & $\mathrm{BP}$ & adherens junction assembly & 0.027114 & THY1; FN1 \\
\hline $\begin{array}{l}\text { GO: } \\
0005178\end{array}$ & MF & integrin binding & $2.56 \mathrm{E}-07$ & THY1; TGFBI; NOV; FN1; THBS4; EDIL3, etc \\
\hline \multicolumn{5}{|c|}{ Antioxidant related pathways } \\
\hline $\begin{array}{l}\text { GO: } \\
0016209\end{array}$ & MF & antioxidant activity & 0.040595 & MGST2; PTGS2; SOD3 \\
\hline $\begin{array}{l}\text { GO: } \\
0004784\end{array}$ & MF & superoxide dismutase activity & 0.047928 & SOD3 \\
\hline $\begin{array}{l}\text { GO: } \\
0006801\end{array}$ & $\mathrm{BP}$ & superoxide metabolic process & 0.00047 & NCF1; SOD3; CYBB \\
\hline $\begin{array}{l}\text { GO: } \\
1901031\end{array}$ & $\mathrm{BP}$ & regulation of response to reactive oxygen species & 0.048995 & HGF \\
\hline $\begin{array}{l}\text { GO: } \\
0050664\end{array}$ & MF & $\begin{array}{l}\text { oxidoreductase activity, acting on } N A D(P) H \text {, oxygen as } \\
\text { acceptor }\end{array}$ & 0.01556 & NCF1; CYBB \\
\hline $\begin{array}{l}\text { GO: } \\
0098869\end{array}$ & BP & cellular oxidant detoxification & 0.040595 & MGST2; PTGS2; SOD3 \\
\hline
\end{tabular}

It can cause phagocytosis of cell debris and release of cytokines, prostaglandins and other signalling proteins, resulting in interstitial spaces [48].

We found that key genes down-regulated in the $\mathrm{H}$ group, such as MYOZ2, were involved in muscle development, cell adhesion, cell matrix, collagen, and cytoskeleton. MYOZ2 belongs to sarcomeric family and links calcineurin to alpha-actinin at the Z-line of skeletal muscle sarcomere and can play a role in skeletal muscle differentiation and growth [49]. It was suggested that MYOZ2 knockout mice had neuromuscular disease [50].
Also, genes down-regulated in the $\mathrm{H}$ group were involved in cell matrix and collagen pathways. Extracellular matrix (ECM) is a major macromolecule in skeletal muscle and has a substantial effect on meat quality. The remodelling of ECM is mainly regulated by matrix metalloproteinases. The expression of matrix metalloproteinase- 1 is negatively correlated with cooking loss and positively correlated with hydraulic performance [51]. Collagen is an abundant connective tissue protein that is an important factor in the tenderness and texture of the meat and is well resistant to physical damage during cooking [52]. The addition of 


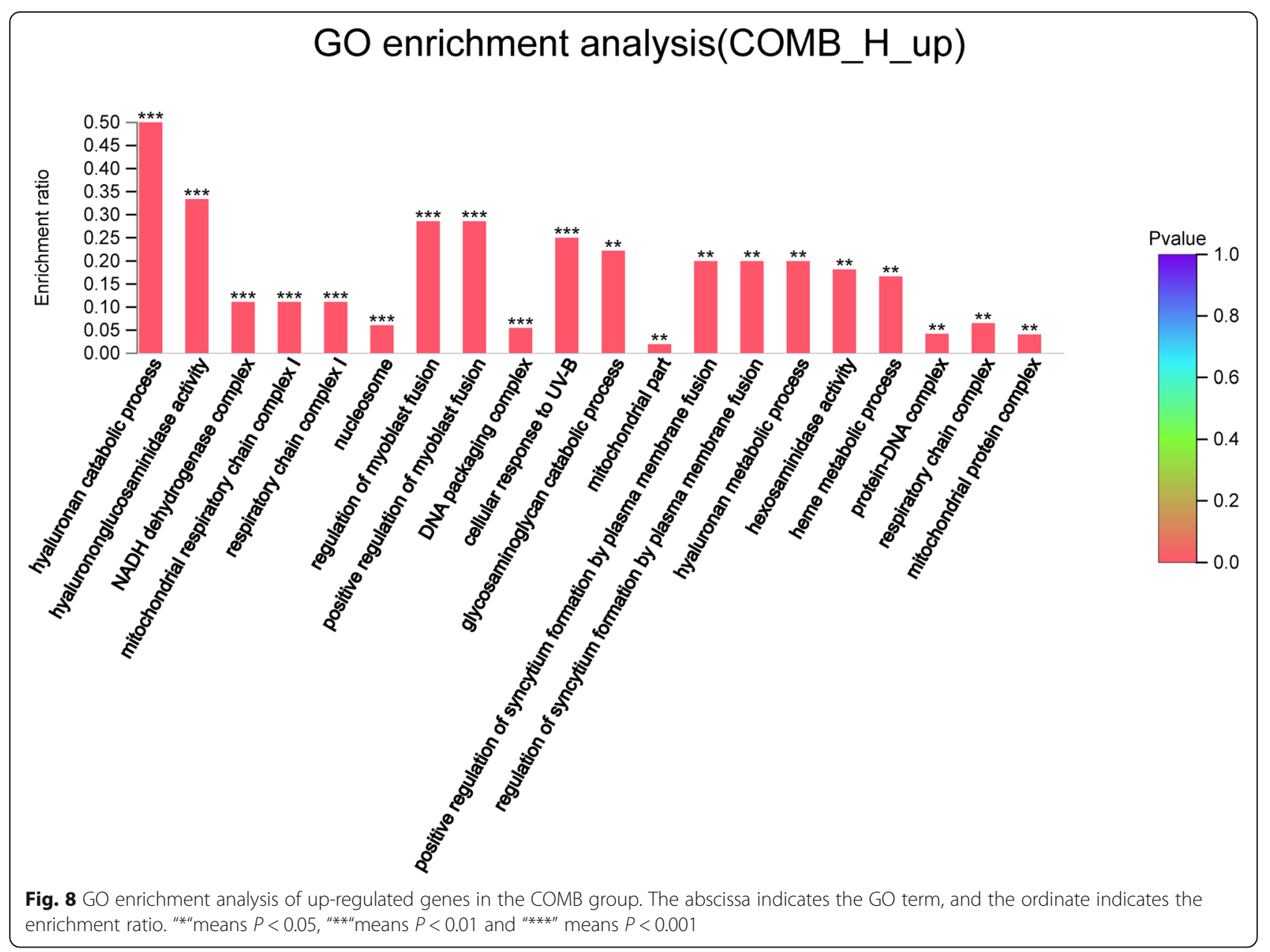

collagen increases the ability of pork [53] and poultry [54] to combine with water and reduces cooking losses. Furthermore, high stocking density downregulates cell adhesion, cytoskeletal and integrin binding-related genes such as integrin subunit alpha 8 (ITGA8), integrin subunit beta 8 (ITGB8) and integrin subunit beta like 1 (ITGBL1). Proteolytic degradation of cell adhesion proteins is associated with the production of drip channels [55]. The cytoskeleton is a highly complex network composed of a large number of connections between myofibrils and myofibrillar membranes. Degradation of the cytoskeleton causes extracellular water to flow into the muscle cells, thereby increasing drip loss [56]. Integrins are heterodimeric cell adhesion molecules that bind the extracellular matrix to the cytoskeleton and play an essential role in controlling cell membrane-cytoskeletal attachment and signalling pathways [57]. The $\beta$-chain integrin is responsible for the attachment of the cell membrane to the cytoskeleton [58]. Degradation of $\beta 1$ integrin promotes the formation of water channels between cells and cell membranes, thereby increasing drip loss [59]. In addition, it has been found that integrins are inversely related to pork drip loss [60].
Compared with the $\mathrm{H}$ group, the COMB group showed up-regulation of muscle development, hyaluronic acid levels, mitochondrial function, and the redox pathway. Studies have found that hyaluronic acid is a crucial water-holding molecule [61, 62]. Furthermore, supplementation with antioxidant isoflavones can be achieved by reducing lipid peroxidation and increasing oxidative stability in the pectoral muscles [63]. Therefore, enhanced hyaluronic acid biosynthesis and antioxidant capacity may improve muscle quality.

Additionally, up-regulated genes in the COMB group involved the complex I-related gene NDUFS5. The mitochondrial respiratory chain (MRC) consists of four membrane-bound electron transport protein complexes (I-IV) and ATP synthase (complex V) that produce ATP for cellular processes. Complex I deficiency, NADH ubiquinone oxidoreductase is the most common form of MRC dysfunction and is associated with a variety of diseases $[64,65]$. Complex I deficiency leads to various physiological disorders such as ATP depletion, calcium homeostasis, ROS accumulation [66] and induction of apoptosis [67]. A study found that mitochondrial and 
Table 10 Muscle development and mitochondria related pathway

\begin{tabular}{|c|c|c|c|c|}
\hline Number & Term Type & Description & $\boldsymbol{P}$-value & Genes \\
\hline \multicolumn{5}{|c|}{ Muscle development related pathways } \\
\hline GO:1901741 & $\mathrm{BP}$ & positive regulation of myoblast fusion & 0.000717 & MYF6 \\
\hline GO:0010831 & $\mathrm{BP}$ & positive regulation of myotube differentiation & 0.003478 & MYF6 \\
\hline GO:0014743 & $\mathrm{BP}$ & regulation of muscle hypertrophy & 0.00447 & LMCD1; TRPC3 \\
\hline GO:0048643 & BP & positive regulation of skeletal muscle tissue development & 0.00447 & MYF6 \\
\hline GO:1901863 & BP & positive regulation of muscle tissue development & 0.020276 & MYF6 \\
\hline GO:0051149 & $\mathrm{BP}$ & positive regulation of muscle cell differentiation & 0.025719 & MYF6 \\
\hline GO:0048743 & $\mathrm{BP}$ & positive regulation of skeletal muscle fiber development & 0.035113 & MYF6 \\
\hline GO:0045844 & BP & positive regulation of striated muscle tissue development & 0.017276 & MYF6 \\
\hline GO:0051155 & $\mathrm{BP}$ & positive regulation of striated muscle cell differentiation & 0.011102 & MYF6 \\
\hline GO:0048636 & $\mathrm{BP}$ & positive regulation of muscle organ development & 0.017276 & MYF6 \\
\hline GO:0014744 & $\mathrm{BP}$ & positive regulation of muscle adaptation & 0.023546 & TRPC3 \\
\hline \multicolumn{5}{|c|}{ Mitochondria related pathways } \\
\hline GO:0042775 & $\mathrm{BP}$ & mitochondrial ATP synthesis coupled electron transport & 0.023546 & NDUFV1 \\
\hline GO:0022904 & $\mathrm{BP}$ & respiratory electron transport chain & 0.025719 & NDUFV1 \\
\hline GO:0022900 & $\mathrm{BP}$ & electron transport chain & 0.029237 & NDUFV1 \\
\hline GO:0098803 & CC & respiratory chain complex & 0.002546 & NDUFV1; NDUFS5; NDUFB2 \\
\hline GO:0045271 & CC & respiratory chain complex I & 0.000532 & NDUFV1; NDUFS5; NDUFB2 \\
\hline GO:0005747 & CC & mitochondrial respiratory chain complex I & 0.000532 & NDUFV1; NDUFS5; NDUFB2 \\
\hline GO:0098798 & CC & mitochondrial protein complex & 0.002727 & TOMM6; NDUFV1; NDUFS5; NDUFB2 \\
\hline GO:0098800 & CC & inner mitochondrial membrane protein complex & 0.009305 & NDUFV1; NDUFS5; NDUFB2 \\
\hline GO:0005742 & CC & mitochondrial outer membrane translocase complex & 0.046544 & TOMм6 \\
\hline GO:0098779 & BP & mitophagy in response to mitochondrial depolarization & 0.04939 & LMCD1; ZNF593 \\
\hline
\end{tabular}

Table 11 Hyaluronan and redox related pathway

\begin{tabular}{|c|c|c|c|c|}
\hline Number & Term Type & Description & $P$-value & Genes \\
\hline \multicolumn{5}{|c|}{ Hyaluronan related pathways } \\
\hline GO:0030213 & $\mathrm{BP}$ & hyaluronan biosynthetic process & 0.023546 & HYAL1 \\
\hline GO:0030214 & $\mathrm{BP}$ & hyaluronan catabolic process & 0.000207 & HYAL3; HYAL1 \\
\hline GO:0030212 & $\mathrm{BP}$ & hyaluronan metabolic process & 0.001519 & HYAL3; HYAL1 \\
\hline GO:1900106 & $\mathrm{BP}$ & positive regulation of hyaluranon cable assembly & 0.017711 & HYAL1 \\
\hline GO:0004415 & MF & hyalurononglucosaminidase activity & 0.000514 & HYAL3; HYAL1 \\
\hline GO:0033906 & MF & hyaluronoglucuronidase activity & 0.011842 & HYAL3 \\
\hline GO:0036117 & $\mathrm{CC}$ & hyaluranon cable & 0.011842 & HYAL1 \\
\hline GO:0050501 & MF & hyaluronan synthase activity & 0.017711 & HYAL1 \\
\hline GO:0006027 & $\mathrm{BP}$ & glycosaminoglycan catabolic process & 0.00122 & HYAL3; HYAL1 \\
\hline GO:0030203 & BP & glycosaminoglycan metabolic process & 0.039481 & HYAL3; HYAL1 \\
\hline GO:0006026 & BP & aminoglycan catabolic process & 0.003025 & HYAL3; HYAL1 \\
\hline GO:1903510 & $\mathrm{BP}$ & mucopolysaccharide metabolic process & 0.013602 & HYAL3; HYAL1 \\
\hline \multicolumn{5}{|c|}{ Redox related pathways } \\
\hline GO:0055114 & $\mathrm{BP}$ & oxidation-reduction process & 0.028445 & LDHD; CPOX; SUOX; NDUFV1; GRHPR; DOHH; NDUFA2 \\
\hline GO:1990204 & $\mathrm{CC}$ & oxidoreductase complex & 0.006475 & NDUFV1; NDUFS5; NDUFB2 \\
\hline GO:0016491 & MF & oxidoreductase activity & 0.045293 & LDHD; CPOX; SUOX; NDUFV1; GRHPR; DOHH \\
\hline GO:0016651 & MF & oxidoreductase activity, acting on $\mathrm{NAD}(\mathrm{P}) \mathrm{H}$ & 0.045042 & NDUFV1 \\
\hline GO:0051287 & MF & NAD binding & 0.031684 & NDUFV1; GRHPR \\
\hline GO:0070402 & MF & NADPH binding & 0.040845 & GRHPR \\
\hline GO:0030964 & CC & NADH dehydrogenase complex & 0.000532 & NDUFV1; NDUFS5; NDUFB2 \\
\hline
\end{tabular}




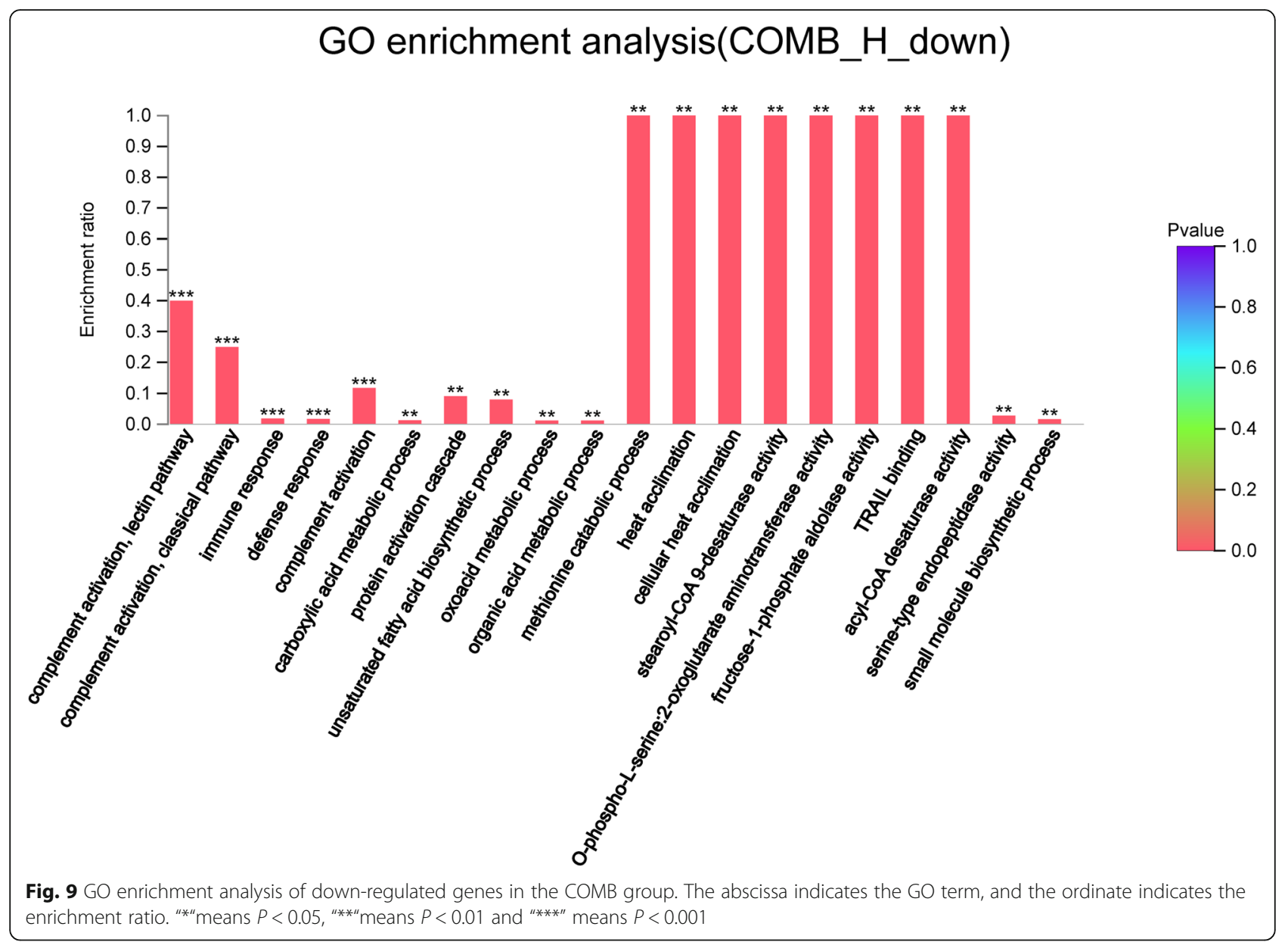

Table 12 Immune response and inflammatory response related pathways

\begin{tabular}{|c|c|c|c|c|}
\hline Number & Term Type & Description & $P$-value & Genes \\
\hline \multicolumn{5}{|c|}{ Immune response and inflammatory response related pathways } \\
\hline GO:0006954 & $\mathrm{BP}$ & inflammatory response & 0.004612 & CCR5; ALOX5 \\
\hline GO:0002532 & $\mathrm{BP}$ & production of molecular mediator involved in inflammatory response & 0.01346 & ALOX5 \\
\hline GO:0002538 & $\mathrm{BP}$ & arachidonic acid metabolite production involved in inflammatory response & 0.008097 & ALOX5 \\
\hline GO:0002540 & $\mathrm{BP}$ & leukotriene production involved in inflammatory response & 0.008097 & ALOX5 \\
\hline GO:0002253 & $\mathrm{BP}$ & activation of immune response & 0.005145 & C1S; BLK \\
\hline GO:0050778 & $\mathrm{BP}$ & positive regulation of immune response & 0.017271 & C1S; BLK \\
\hline GO:0045087 & $\mathrm{BP}$ & innate immune response & 0.005036 & C1S; BLK \\
\hline GO:0006956 & $\mathrm{BP}$ & complement activation & 0.000944 & C1S \\
\hline GO:0001867 & $\mathrm{BP}$ & complement activation, lectin pathway & 7.08E-05 & C1S \\
\hline GO:0006958 & $\mathrm{BP}$ & complement activation, classical pathway & 0.000197 & C1S \\
\hline GO:0004950 & MF & chemokine receptor activity & 0.047636 & CCR5 \\
\hline GO:0016493 & MF & C-C chemokine receptor activity & 0.024101 & CCR5 \\
\hline GO:0090026 & $\mathrm{BP}$ & positive regulation of monocyte chemotaxis & 0.024101 & CCR5 \\
\hline GO:0002495 & $\mathrm{BP}$ & antigen processing and presentation of peptide antigen via MHC class II & 0.032008 & MARCH1 \\
\hline GO:0042287 & MF & MHC protein binding & 0.045049 & MARCH1 \\
\hline
\end{tabular}


Table 13 Organic acid, faty acid metabolic process, glycolytic and carbohydrate metabolism related pathways

\begin{tabular}{|c|c|c|c|c|}
\hline Number & Term Type & Description & $P$-value & Genes \\
\hline \multicolumn{5}{|c|}{ Organic acid and faty acid metabolic process related pathways } \\
\hline GO:0006082 & $\mathrm{BP}$ & organic acid metabolic process & 0.002344 & PSAT1; SCD; MAT1A; ALOX5; ST3GAL1; ALDOB \\
\hline GO:0016053 & $\mathrm{BP}$ & organic acid biosynthetic process & 0.006961 & PSAT1; SCD; ALOX5 \\
\hline GO:0043436 & $\mathrm{BP}$ & oxoacid metabolic process & 0.002254 & PSAT1; SCD; MAT1A; ALOX5; ST3GAL1; ALDOB \\
\hline GO:0046394 & $\mathrm{BP}$ & carboxylic acid biosynthetic process & 0.006961 & PSAT1; SCD; ALOX5 \\
\hline GO:0019752 & $\mathrm{BP}$ & carboxylic acid metabolic process & 0.001555 & PSAT1; SCD; MAT1A; ALOX5; ST3GAL1; ALDOB \\
\hline GO:0006633 & $\mathrm{BP}$ & fatty acid biosynthetic process & 0.012538 & SCD; ALOX5 \\
\hline GO:0006636 & $\mathrm{BP}$ & unsaturated fatty acid biosynthetic process & 0.002054 & SCD; ALOX5 \\
\hline GO:0016215 & MF & acyl-CoA desaturase activity & 0.002706 & SCD \\
\hline \multicolumn{5}{|c|}{ Glycolytic and carbohydrate metabolism related pathways } \\
\hline GO:0030388 & $\mathrm{BP}$ & fructose 1,6-bisphosphate metabolic process & 0.01613 & ALDOB \\
\hline GO:0006000 & $\mathrm{BP}$ & fructose metabolic process & 0.018794 & ALDOB \\
\hline GO:0070061 & MF & fructose binding & 0.010782 & ALDOB \\
\hline GO:0061609 & MF & fructose-1-phosphate aldolase activity & 0.002706 & ALDOB \\
\hline GO:0004332 & MF & fructose-bisphosphate aldolase activity & 0.010782 & ALDOB \\
\hline GO:0005975 & $\mathrm{BP}$ & carbohydrate metabolic process & 0.029095 & GALNT16; ST3GAL1; ALDOB \\
\hline GO:0030246 & MF & carbohydrate binding & 0.041651 & GALNT16; ALDOB \\
\hline
\end{tabular}

oxidative phosphorylation-related gene expression was negatively correlated with drip loss. A negative correlation with drip loss means that there is a decrease in the number of mitochondria in muscles with high drip loss [68].

\section{Conclusion}

High stocking density may cause oxidative stress, abnormal muscle contraction, and abnormal metabolism of glycolipids; destroy ion channels and cell matrix; reduce muscle strength by inhibiting muscle development, and cell adhesion and collagen synthesis, all of which result in reduced muscle function. Supplementation with
NAM and BA in combination can improve mitochondrial function and antioxidant capacity, and inhibit inflammatory response and glycolysis by promoting muscle development and hyaluronic acid synthesis, thereby reducing drip loss of the breast muscle and improving muscle quality (Fig. 11).

\section{Methods}

Experimental birds, diets, and management

Amount of 300 Cobb broilers (21-day-old) were divided into 3 groups: low stocking density $\left(\mathrm{L}, 14 \mathrm{birds} / \mathrm{m}^{2}\right)$, high stocking density $\left(\mathrm{H}, 18\right.$ birds $\left./ \mathrm{m}^{2}\right)$ and combination of NAM and BA (COMB, 18 birds $/ \mathrm{m}^{2}$ ), with 6 replicates

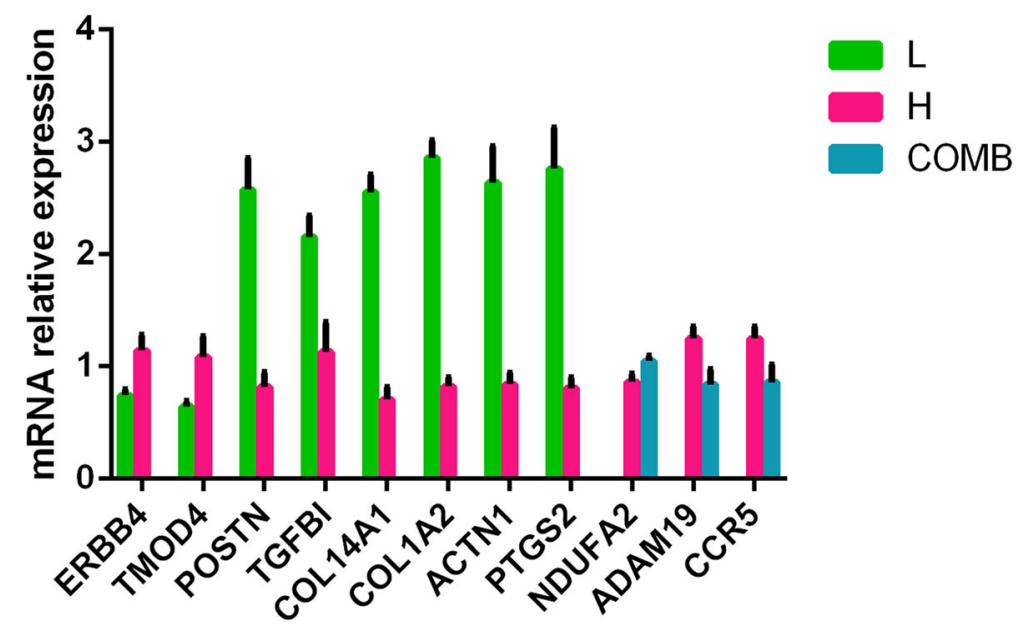

Fig. 10 The mRNA relative expression of DEGs quantified by quantitative reverse transcription-PCR. Data presented as means \pm SEM 


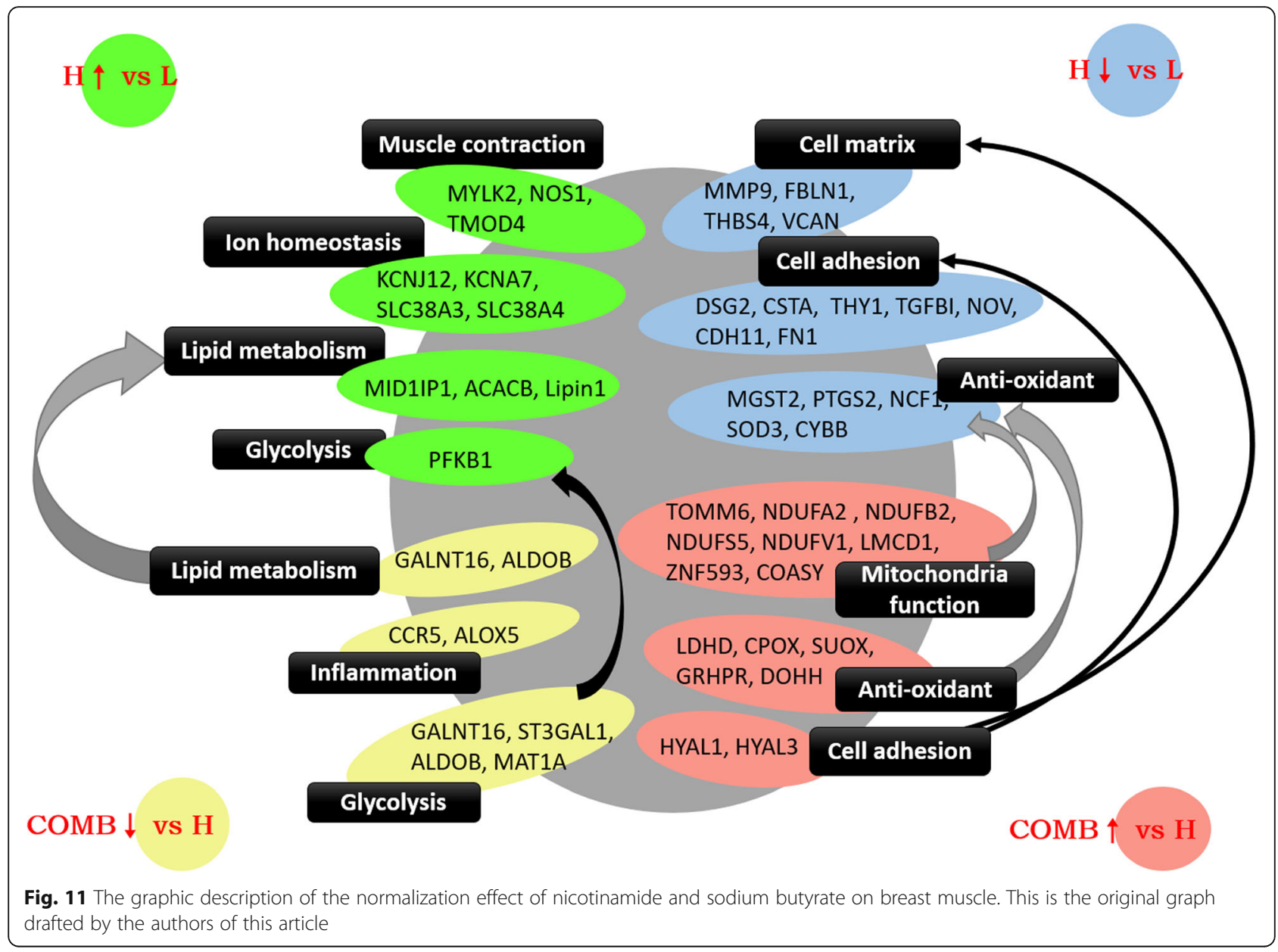

for each group. The stocking densities of this study are referred to Vargas-Galicia et al. [69]. The $\mathrm{L}$ and $\mathrm{H}$ groups were fed a basal diet. The COMB group was fed basal diet supplemented with $50 \mathrm{mg} / \mathrm{kg}$ NAM and 500 $\mathrm{mg} / \mathrm{kg}$ BA. The dosage $50 \mathrm{mg} / \mathrm{kg}$ NAM and $500 \mathrm{mg} / \mathrm{kg}$ BA used in this study were based on our previous studies [70, 71]. Experimental diets were designed to meet nutrient requirements of National Research Council (1994) [72]. The nutrient levels and composition of basic diet were shown in Table 14. Broilers in this study were raised from 21-day-old to 42-day-old, and feed and water were provided ad libitum.

\section{Production performance determination and sample collection}

On 42-day, remove feed for $5 \mathrm{~h}$ and record the remaining feed per cage, then weight the body weight (BW) of broilers. Calculate body weight gain (BWG), feed intake (FI) and the feed conversion rate (FCR).

For breast collection, one broiler per replicate was randomly selected and euthanized by intravenous injection of pentobarbital sodium $(390 \mathrm{mg} / \mathrm{ml})$ at a dose of 300 $\mathrm{mg} / \mathrm{kg}$. The breast muscle was collected for meat quality analysis and further study.

Each group had six replicates for the determination of meat quality, enzyme activities and mRNA relative expression; there were three biology replicates in each group for RNA-sequencing.

\section{Meat quality analysis}

The meat quality of right side major pectoral muscle was quickly determined after slaughtering. The drip loss was determined according to Liu et al. [73]. Cooking loss was measured according to the protocol described by Cai et al. [74]. The $\mathrm{pH}$ values of the pectoral muscle at $45 \mathrm{~min}$ and $24 \mathrm{~h}$ were measured by a $\mathrm{pH}$ meter (testo 205; Germany). Each sample was tested at 3 different locations (top, middle and bottom) and the average of 3 measurements was calculated.

\section{Enzyme activity determination in breast muscle}

The total antioxidant capacity (T-AOC, cat\#A015), antisuperoxide anion (cat\#A052), the activities of creatine kinase (CK, cat\#A032), lactate dehydrogenase (LDH, cat\#A020-2), malic dehydrogenase (MDH, cat\#A021-2), 
Table 14 The composition and nutrient level of basal diet

\begin{tabular}{llll}
\hline Ingredient & Percent & Nutrients & Percent \\
\hline Corn & 62.05 & Metabolic energy & 3100 Kcal \\
Soybean meal & 26.90 & Crude Protein & 18.98 \\
Corn Gluten Meal & 4.00 & Lysine & 1.04 \\
Soybean oil & 3.10 & Methionine & 0.49 \\
DL-Methionine & 0.18 & Threonine & 0.74 \\
L-Lysine sulphate & 0.40 & Tryptophan & 0.24 \\
Sodium chloride & 0.30 & Calcium & 0.86 \\
Choline chloride (50\%) & 0.15 & Available Phosphorus & 0.32 \\
Vitamin premix & 0.02 & Met+Cys & 0.80 \\
Trace mineral premix & 0.20 & & \\
Dicalcium phosphate & 1.40 & & \\
Limestone & 1.20 & & \\
Phytase & 0.02 & & \\
Antioxidant & 0.03 & & \\
Medical stone & 0.05 & &
\end{tabular}

${ }^{\mathrm{a}}$ The trace mineral premix provided the following per kg of diets: $\mathrm{Cu}, 16 \mathrm{mg}$ (as $\mathrm{CuSO}_{4} \cdot 5 \mathrm{H}_{2} \mathrm{O}$ ); $\mathrm{Zn}, 110 \mathrm{mg}$ (as $\mathrm{ZnSO}_{4}$ ); $\mathrm{Fe}, 80 \mathrm{mg}$ (as $\mathrm{FeSO}_{4} \cdot \mathrm{H}_{2} \mathrm{O}$ ); $\mathrm{Mn}, 120 \mathrm{mg}$ (as $\mathrm{MnO}$ ); $\mathrm{Se}, 0.3 \mathrm{mg}$ (as $\mathrm{Na}_{2} \mathrm{SeO}_{3}$ ); I, $1.5 \mathrm{mg}$ (as KI); $\mathrm{Co}, 0.5 \mathrm{mg}$

${ }^{\mathrm{b}}$ The vitamin premix provided the following per kg of diets: vitamin $\mathrm{A}, 10,000$ IU; vitamin D3, 2400 IU; vitamin E, 20 mg; vitamin $\mathrm{K} 3,2 \mathrm{mg}$; vitamin $\mathrm{B} 1,2 \mathrm{mg}$; vitamin B2, $6.4 \mathrm{mg}$; VB6, $3 \mathrm{mg}$; VB12, $0.02 \mathrm{mg}$; biotin, $0.1 \mathrm{mg}$; folic acid, $1 \mathrm{mg}$; pantothenic acid, $10 \mathrm{mg}$; nicotinamide, $30 \mathrm{mg}$

'Met+Cys: Methionine+ Cysteine

and the content of hydroxyproline (cat\# A030-2) in breast muscle were measured by commercial analytical kits (Jian Cheng Bioengineering Institute, Nanjing, China).

RNA extraction, library preparation and Illumina Hiseq $\mathrm{X}$ ten sequencing

Total RNA from the breast muscle was extracted by TRIzol $^{\circ}$ Reagent (Invitrogen, Carlsbad, CA, USA). The RNA quality was then measured by 2100 Bioanalyser (Agilent Technologies, Santa Clara, CA, USA) and quantified using the ND-2000 (Nanodrop Technologies, Wilmington, Delaware).

RNA-seq library was constructed according to TruSeqTM RNA sample preparation Kit from Illumina (San Diego, CA, USA), then was sequenced with the Illumina HiSeq X Ten $(2 \times 150$ bp read length).

\section{Read mapping, differential expression analysis and functional enrichment}

SeqPrep and Sickle were applied to process raw pairedend reads. Then use TopHat version2.0.0 [75] software to align the clean reads to the reference genome.

FRKM method was applied to identify differentially expressed genes (DEGs). RSEM [76] was used to quantify gene abundances. Differential gene expression was analyzed by $\mathrm{R}$ statistical package software Edge R [77].
Table 15 Real time PCR primer sequence

\begin{tabular}{|c|c|c|c|}
\hline Gene & Primer sequence $\left(5^{\prime}-3^{\prime}\right)$ & Size & Accession NO. \\
\hline \multirow[t]{2}{*}{ GAPDH } & $\begin{array}{l}\text { Forward: GGTAGTGAAGGCTGCTGC } \\
\text { TGATG }\end{array}$ & \multirow[t]{2}{*}{200} & \multirow[t]{2}{*}{ NM_204305.1 } \\
\hline & $\begin{array}{l}\text { Reverse: AGTCCACAACACGGTTGC } \\
\text { TGTATC }\end{array}$ & & \\
\hline \multirow[t]{2}{*}{ ERBB4 } & $\begin{array}{l}\text { Forward: ATCACCAGCATCGAGCAC } \\
\text { AACAG }\end{array}$ & \multirow[t]{2}{*}{114} & \multirow[t]{2}{*}{$\begin{array}{l}\mathrm{NM}_{-} \\
001030365.1\end{array}$} \\
\hline & $\begin{array}{l}\text { Reverse: CAGGTTCTCCAGTGGCAGGTAT } \\
\text { TC }\end{array}$ & & \\
\hline \multirow[t]{2}{*}{ TMOD4 } & $\begin{array}{l}\text { Forward: GATGGAGATGGCGACGAT } \\
\text { GCTG }\end{array}$ & \multirow[t]{2}{*}{135} & \multirow[t]{2}{*}{ NM_204774.1 } \\
\hline & $\begin{array}{l}\text { Reverse: TTCTTCTGCTTGCGACGG } \\
\text { AGTTC }\end{array}$ & & \\
\hline \multirow[t]{2}{*}{ PTGS2 } & Forward: ACTGCTGGCCGCTCTCCTTG & \multirow[t]{2}{*}{121} & \multirow{2}{*}{$\begin{array}{l}\mathrm{NM}_{-} \\
001167719.1\end{array}$} \\
\hline & $\begin{array}{l}\text { Reverse: CCTCGTGCAGTCACATTCATAC } \\
\text { CG }\end{array}$ & & \\
\hline \multirow[t]{2}{*}{ COLIA2 } & $\begin{array}{l}\text { Forward: TCCTCCTGGTAACAACGG } \\
\text { TCCTG }\end{array}$ & \multirow[t]{2}{*}{85} & \multirow[t]{2}{*}{$\begin{array}{l}\mathrm{NM}_{-} \\
001079714.2\end{array}$} \\
\hline & $\begin{array}{l}\text { Reverse: GAGACCATTGCGACCATCCTTA } \\
\text { CC }\end{array}$ & & \\
\hline \multirow[t]{2}{*}{ POSTN } & $\begin{array}{l}\text { Forward: CAGCCGCATCTGCTCACT } \\
\text { ATGAC }\end{array}$ & \multirow[t]{2}{*}{200} & \multirow[t]{2}{*}{$\mathrm{NM}_{-}$} \\
\hline & $\begin{array}{l}\text { Reverse: CTTCATGTAGCCAGGACA } \\
\text { GCACTC }\end{array}$ & & \\
\hline \multirow[t]{2}{*}{ COL14A1 } & $\begin{array}{l}\text { Forward: CCAACTCAGCCACCAACT } \\
\text { TCTCC }\end{array}$ & \multirow[t]{2}{*}{107} & \multirow[t]{2}{*}{ NM_205334.1 } \\
\hline & $\begin{array}{l}\text { Reverse: TCCACTAGGAACACCAGG } \\
\text { TCAGC }\end{array}$ & & \\
\hline \multirow[t]{2}{*}{ TGFBI } & $\begin{array}{l}\text { Forward: ACCACCACGAACAGCATT } \\
\text { CAGC }\end{array}$ & \multirow[t]{2}{*}{87} & \multirow[t]{2}{*}{ NM_205036.1 } \\
\hline & $\begin{array}{l}\text { Reverse: GTTGAGGTCAGAAGCAGC } \\
\text { CACAG }\end{array}$ & & \\
\hline \multirow[t]{2}{*}{ ACTN1 } & $\begin{array}{l}\text { Forward: GCGTGGAACAGATTGCTG } \\
\text { CTATTG }\end{array}$ & \multirow[t]{2}{*}{88} & \multirow[t]{2}{*}{ NM_204127.1 } \\
\hline & $\begin{array}{l}\text { Reverse: ATCTTCTGGCACCTGGCA } \\
\text { TTGAC }\end{array}$ & & \\
\hline \multirow[t]{2}{*}{ NDUFA2 } & $\begin{array}{l}\text { Forward: CATCGAGCAGCACTACGT } \\
\text { GACTC }\end{array}$ & \multirow[t]{2}{*}{159} & \multirow[t]{2}{*}{$\begin{array}{l}\mathrm{NM}_{-} \\
001302137.1\end{array}$} \\
\hline & $\begin{array}{l}\text { Reverse: TTGGCAACTTCATCCACA } \\
\text { CTGAGG }\end{array}$ & & \\
\hline \multirow[t]{2}{*}{ ADAM19 } & $\begin{array}{l}\text { Forward: GACAGGACAAGCACGGAC } \\
\text { CATC }\end{array}$ & \multirow[t]{2}{*}{166} & \multirow[t]{2}{*}{$\begin{array}{l}\mathrm{NM}_{-} \\
001195122.1\end{array}$} \\
\hline & $\begin{array}{l}\text { Reverse: AGGAAGCGGCTCCAGGAC } \\
\text { ATAG }\end{array}$ & & \\
\hline \multirow[t]{2}{*}{ CCR5 } & Forward: GAGATGCGCTGTGCCGGATTC & \multirow[t]{2}{*}{159} & $N M_{-}$ \\
\hline & Reverse: TGCTGGTGAGGATGCCGTAGG & & \\
\hline
\end{tabular}

Goatools and KOBAS [78] were applied for KEGG pathway enrichment and GO functional analysis.

The mRNA expression of muscle developmental genes Several differentially expressed genes involved muscle development were validated by real-time PCR analysis. The mRNA expression of muscle was determined as we 
previously described [71]. The primer sequences of target gene and housekeeping gene beta-actin were shown in Table 15. The results of gene expression were analyzed and compared using $2^{-\Delta \Delta C T}$.

\section{Statistical analysis}

The results are expressed as means with their standard error mean (SEM). SPSS 20.0 for Windows (SPSS Inc. Chicago, IL) was applied for One-way ANOVA analysis. Significant difference was considered at $P<0.05$.

\section{Supplementary information}

Supplementary information accompanies this paper at https://doi.org/10. 1186/s12864-020-06827-0.

Additional file 1: Figure S1. Inflammatory mediator regulation of RTP channels pathway analysis. Differential expressed genes that are involved in the inflammatory mediator regulation of RTP channels [map 04750], are highlighted. We thank Kanehisa Laboratories for providing the copyright permission of KEGG pathway maps [29].

Additional file 2: Figure S2. Chemokine signaling pathway analysis. Differential expressed genes that are involved in the chemokine signaling pathway [map 04062], are highlighted. We thank Kanehisa Laboratories for providing the copyright permission of KEGG pathway maps [29].

Additional file 3: Figure S3. Calcium signaling pathway analysis. Differential expressed genes that are involved in the calcium signaling pathway [map 04020], are highlighted. We thank Kanehisa Laboratories for providing the copyright permission of KEGG pathway maps [29].

Additional file 4: Figure S4. ECM-receptor interaction pathway analysis. Differential expressed genes that are involved in the inflammatory mediator regulation of RTP channels [map 04512], are highlighted. We thank Kanehisa Laboratories for providing the copyright permission of KEGG pathway maps [29].

Additional file 5: Figure S5. Adherens junction pathway analysis. Differential expressed genes that are involved in the adherens junction [map 04520], are highlighted. We thank Kanehisa Laboratories for providing the copyright permission of KEGG pathway maps [29].

Additional file 6: Figure S6. Focal adhesion pathway analysis. Differential expressed genes that are involved in the focal adhesion [map 04510], are highlighted. We thank Kanehisa Laboratories for providing the copyright permission of KEGG pathway maps [29].

Additional file 7: Fig. S7. Oxidative phosphorylation pathway analysis. Differential expressed genes that are involved in the oxidative phosphorylation [map 00190], are highlighted. We thank Kanehisa Laboratories for providing the copyright permission of KEGG pathway maps [29].

Additional file 8: Figure S8. Regulation of lipolysis in adipocytes pathway analysis. Differential expressed genes that are involved in the Regulation of lipolysis in adipocytes [map 04923], are highlighted. We thank Kanehisa Laboratories for providing the copyright permission of KEGG pathway maps [29].

Additional file 9: Figure S9. Glycolysis/Gluconeogenesis pathway analysis. Differential expressed genes that are involved in the Glycolysis/ Gluconeogenesis [map 00010], are highlighted. We thank Kanehisa Laboratories for providing the copyright permission of KEGG pathway maps [29].

Additional file 10: Figure S10. Arachidonic acid metabolism pathway analysis. Differential expressed genes that are involved in the arachidonic acid metabolism [map 00590], are highlighted. We thank Kanehisa Laboratories for providing the copyright permission of KEGG pathway maps [29].

\section{Abbreviations}

L: Low stocking density group; H: High stocking density group; COMB: A combination of nicotinamide and sodium butyrate group; NAM: Nicotinamide; ROS: Reactive oxygen species; BA: Butyrate sodium; PGC1a: Peroxisome proliferator-activated receptor- $\gamma$ coactivator $1 a$; NAD: Nicotinamide adenine dinucleotide; T-AOC: Total antioxidant capacity; LDH: Lactate dehydrogenase; CK: Creatine kinase; MDH: Malic dehydrogenase; DEGs: Differentially expressed genes; NOS1: Nitric oxide synthase 1; KEAP1: Kelch-Like ECH-associated protein 1; CDKN1A: Cyclindependent kinase inhibitor $1 \mathrm{~A}$

\section{Acknowledgments}

We would like to thank Dr. Adam John Rose from Monash University for his critical revision and suggestions.

\section{Authors' contributions}

JMY conceived and designed the experiment; YQW, YLW, DFY performed the experiments. YOW analyzed RNA Sequencing data and drafted the manuscript. TM and JMY reviewed and edited the manuscript. All authors critically revised the manuscript for important intellectual content and all approved the final version of this manuscript.

\section{Funding}

This research was funded by the National Key Research and Development Program of China (Project Number: 2016YFD0500509-9) and the System for Poultry Production Technology, Beijing Agriculture Innovation Consortium (Project Number: BAIC04-2019). The funder had no role in study design, data collection and analysis, data interpretation or preparation of the manuscript.

Availability of data and materials

All the sequencing data are deposited in SRA under the Bioproject accession number PRJNA558637.

Ethics approval and consent to participate

All procedures used in our experiments were approved by the Institutional Animal Care and Use Committee of the China Agricultural University (Beijing, China, permit number SYXK20130013)

\section{Consent for publication}

Not applicable.

\section{Competing interests}

The authors declare that they have no competing interests.

Received: 22 August 2019 Accepted: 15 June 2020

Published online: 18 June 2020

References

1. Najafi P, Zulkifli I, Jajuli NA, Farjam AS, Ramiah SK, Amir AA, O'Reily E, Eckersall D. Environmental temperature and stocking density effects on acute phase proteins, heat shock protein 70, circulating corticosterone and performance in broiler chickens. Int J Biometeorol. 2015;59(11):1577-83.

2. Zhang YR, Zhang LS, Wang Z, Liu Y, Li FH, Yuan JM, Xia ZF. Effects of stocking density on growth performance, meat quality and tibia development of Pekin ducks. Anim Sci J. 2018;89(6):925-30

3. Patria C, Afnan R, Arief II. Physical and microbiological qualities of kampongbroiler crossbred chickens meat raised in different stocking densities. Media Peternakan. 2016:39(3):141-7.

4. Falowo $A B$, Fayemi PO, Muchenje V. Natural antioxidants against lipidprotein oxidative deterioration in meat and meat products: a review. Food Res Int. 2014;64:171-81.

5. Zhang L, Yue HY, Wu SG, Xu L, Zhang HJ, Yan HJ, Cao YL, Gong YS, Qi GH. Transport stress in broilers. II. Superoxide production, adenosine phosphate concentrations, and mRNA levels of avian uncoupling protein, avian adenine nucleotide translocator, and avian peroxisome proliferator-activated receptor-gamma coactivator-1alpha in skeletal muscles. Poult Sci. 2010;89(3): 393-400

6. Selman C, MCLaren JS, Himanka MJ, Speakman JR. Effect of long-term cold exposure on antioxidant enzyme activities in a small mammal. Free Radic Biol Med. 2000;28(8):1279-85. 
7. Zhang C, Yang L, Zhao X, Chen X, Wang L, Geng Z. Effect of dietary resveratrol supplementation on meat quality, muscle antioxidative capacity and mitochondrial biogenesis of broilers. J Sci Food Agric. 2018;98(3):1216-21.

8. Choi HJ, Jang SY, Hwang ES. High-dose Nicotinamide suppresses ROS generation and augments population expansion during CD8(+) T cell activation. Mol Cells. 2015;38(10):918-24.

9. Kwak JY, Ham HJ, Kim CM, Hwang ES. Nicotinamide exerts antioxidative effects on senescent cells. Mol Cells. 2015;38(3):229-35.

10. Mitchell SJ, Bernier M, Aon MA, Cortassa S, Kim EY, Fang EF, Palacios HH, Ali A, Navas-Enamorado I, Di Francesco A, et al. Nicotinamide Improves Aspects of Healthspan, but Not Lifespan, in Mice. Cell Metab. 2018;27(3):667-676.e4.

11. Jahns F, Wilhelm A, Jablonowski N, Mothes H, Greulich KO, Glei M. Butyrate modulates antioxidant enzyme expression in malignant and non-malignant human colon tissues. Mol Carcinog. 2015;54(4):249-60.

12. Zhang WH, Jiang Y, Zhu QF, Gao F, Dai SF, Chen J, Zhou GH. Sodium butyrate maintains growth performance by regulating the immune response in broiler chickens. Brit Poultry Sci. 2011;52(3):292-301.

13. Walsh ME, Bhattacharya A, Sataranatarajan K, Qaisar R, Sloane L, Rahman MM, Kinter M, Van Remmen H. The histone deacetylase inhibitor butyrate improves metabolism and reduces muscle atrophy during aging. Aging Cell. 2015;14(6):957-70.

14. Jiang RR, Zhao GP, Chen JL, Zheng MQ, Zhao JP, Li P, Hu J, Wen J. Effect of dietary supplemental nicotinic acid on growth performance, carcass characteristics and meat quality in three genotypes of chicken. J Anim Physiol Anim Nutr (Berl). 2011;95(2):137-45.

15. Panda A, Rao S, Raju M, Sunder GS. Effect of butyric acid on performance, gastrointestinal tract health and carcass characteristics in broiler chickens. Asian-Australas J Anim Sci. 2009;22(7):1026-31.

16. Xiong J, Qiu H, Bi Y, Zhou H, Guo S, Ding B. Effects of dietary supplementation with Tributyrin and coated sodium butyrate on intestinal morphology, Disaccharidase activity and intramuscular fat of lipopolysaccharide-challenged broilers. Braz J Poult Sci. 2018;20(4):707-16.

17. Wenz T, Rossi SG, Rotundo RL, Spiegelman BM, Moraes $C T$. Increased muscle PGC-1alpha expression protects from sarcopenia and metabolic disease during aging. Proc Natl Acad Sci U S A. 2009;106(48):20405-10.

18. Mouchiroud L, Houtkooper RH, Moullan N, Katsyuba E, Ryu D, Canto C, Mottis A, Jo YS, Viswanathan M, Schoonjans K, et al. The NAD(+)/Sirtuin pathway modulates longevity through activation of mitochondrial UPR and FOXO signaling. Cell. 2013;154(2):430-41.

19. Zhang H, Ryu D, Wu Y, Gariani K, Wang X, Luan P, D'Amico D, Ropelle ER, Lutolf $M P$, Aebersold R, et al. NAD(+) repletion improves mitochondrial and stem cell function and enhances life span in mice. Science. 2016;352(6292):1436-43.

20. Hathorn T, Snyder-Keller A, Messer A. Nicotinamide improves motor deficits and upregulates PGC-1alpha and BDNF gene expression in a mouse model of Huntington's disease. Neurobiol Dis. 2011;41(1):43-50.

21. Frederick DW, Loro E, Liu L, Davila A Jr, Chellappa K, Silverman IM, Quinn WJ 3rd, Gosai SJ, Tichy ED, Davis JG, et al. Loss of NAD homeostasis leads to progressive and reversible degeneration of skeletal muscle. Cell Metab. 2016;24(2):269-82

22. Goody MF, Kelly MW, Reynolds CJ, Khalil A, Crawford BD, Henry CA. NAD+ biosynthesis ameliorates a zebrafish model of muscular dystrophy. PLoS Biol. 2012;10(10):e1001409.

23. Vrablik TL, Wang W, Upadhyay A, Hanna-Rose W. Muscle type-specific responses to NAD+ salvage biosynthesis promote muscle function in Caenorhabditis elegans. Dev Biol. 2011;349(2):387-94.

24. Khan M, Ringseis R, Mooren FC, Kruger K, Most E, Eder K. Niacin supplementation increases the number of oxidative type I fibers in skeletal muscle of growing pigs. BMC Vet Res. 2013;9:177.

25. Khan M, Couturier A, Kubens JF, Most E, Mooren FC, Kruger K, Ringseis R, Eder K. Niacin supplementation induces type II to type I muscle fiber transition in skeletal muscle of sheep. Acta Vet Scand. 2013;55:85.

26. Gao Z, Yin J, Zhang J, Ward RE, Martin RJ, Lefevre M, Cefalu WT, Ye J. Butyrate improves insulin sensitivity and increases energy expenditure in mice. Diabetes. 2009:58(7):1509-17.

27. Huang $Y$, Gao S, Jun G, Zhao R, Yang X. Supplementing the maternal diet of rats with butyrate enhances mitochondrial biogenesis in the skeletal muscles of weaned offspring. Br J Nutr. 2017;117(1):12-20.

28. Henagan TM, Stefanska B, Fang Z, Navard AM, Ye J, Lenard NR, Devarshi PP. Sodium butyrate epigenetically modulates high-fat diet-induced skeletal muscle mitochondrial adaptation, obesity and insulin resistance through nucleosome positioning. Br J Pharmacol. 2015;172(11):2782-98.
29. Kanehisa M, Goto S. KEGG: Kyoto encyclopedia of genes and genomes. Nucleic Acids Res. 2000;28(1):27-30

30. Van Laack RL, Liu CH, Smith MO, Loveday HD. Characteristics of pale, soft, exudative broiler breast meat. Poult Sci. 2000;79(7):1057-61.

31. Mudalal S, Lorenzi M, Soglia F, Cavani C, Petracci M. Implications of white striping and wooden breast abnormalities on quality traits of raw and marinated chicken meat. Animal. 2015;9(4):728-34.

32. Zhang W, Marwan AH, Samaraweera H, Lee EJ, Ahn DU. Breast meat quality of broiler chickens can be affected by managing the level of nitric oxide. Poult Sci. 2013;92(11):3044-9.

33. Wang J, Song C, Cao X, Li H, Cai H, Ma Y, Huang Y, Lan X, Lei C, Ma Y, et al. MiR-208b regulates cell cycle and promotes skeletal muscle cell proliferation by targeting CDKN1A. J Cell Physiol. 2019;234(4):3720-9.

34. Kensler TW, Wakabayashi N, Biswal S. Cell survival responses to environmental stresses via the Keap1-Nrf2-ARE pathway. Annu Rev Pharmacol Toxicol. 2007;47:89-116

35. Wang RR, Pan XJ, Peng ZQ. Effects of heat exposure on muscle oxidation and protein functionalities of pectoralis majors in broilers. Poult Sci. 2009; 88(5):1078-84.

36. Wimmers $\mathrm{K}$, Murani E, Ponsuksili S. Functional genomics and genetical genomics approaches towards elucidating networks of genes affecting meat performance in pigs. Brief Funct Genomics. 2010;9(3):251-8.

37. Huang JC, Yang J, Huang M, Zhu ZS, Sun XB, Zhang BH, Xu XL, Meng WG, Chen $\mathrm{KJ}, \mathrm{Xu} \mathrm{BC}$. Effect of pre-slaughter shackling and wing flapping on plasma parameters, postmortem metabolism, AMPK, and meat quality of broilers. Poult Sci. 2018:97(5):1841-7.

38. Zeferino CP, Komiyama CM, Pelicia VC, Fascina VB, Aoyagi MM, Coutinho LL, Sartori JR, Moura AS. Carcass and meat quality traits of chickens fed diets concurrently supplemented with vitamins $C$ and $E$ under constant heat stress. Animal. 2016;10(1):163-71.

39. Huang JC, Yang J, Huang F, Huang M, Chen KJ, Xu XL, Zhou GH. Effect of fast pH decline during the early postmortem period on calpain activity and cytoskeletal protein degradation of broiler M. pectoralis major. Poult Sci. 2016;95(10):2455-63.

40. Marchesi J, Ibelli A, Peixoto JO, Cantao ME, Pandolfi J, Marciano C, Zanella R, Settles ML, Coutinho LL, Ledur MC. Whole transcriptome analysis of the pectoralis major muscle reveals molecular mechanisms involved with white striping in broiler chickens. Poult Sci. 2019:98(2):590-601.

41. Wu W, Huang R, Wu Q, Li P, Chen J, Li B, Liu H. The role of Six 1 in the genesis of muscle cell and skeletal muscle development. Int J Biol Sci. 2014; 10(9):983-9.

42. Sakakibara I, Wurmser M, Dos Santos M, Santolini M, Ducommun S, Davaze R, Guernec A, Sakamoto K, Maire P. Six 1 homeoprotein drives myofiber type IIA specialization in soleus muscle. Skelet Muscle. 2016;6(1):30.

43. Ryu YC, Lee MH, Lee SK, Kim BC. Effects of muscle mass and fiber type composition of longissimus dorsi muscle on postmortem metabolic rate and meat quality in pigs. J Muscle Foods. 2006;17(3):343-53.

44. Strasburg GM, Chiang W. Pale, soft, exudative Turkey--the role of ryanodine receptor variation in meat quality. Poult Sci. 2009:88(7):1497-505.

45. Sandercock DA, Mitchell MA. The role of sodium ions in the pathogenesis of skeletal muscle damage in broiler chickens. Poult Sci. 2004;83(4):701-6.

46. Sandercock DA, Barker ZE, Mitchell MA, Hocking PM. Changes in muscle cell cation regulation and meat quality traits are associated with genetic selection for high body weight and meat yield in broiler chickens. Genet Se Evol. 2009:41(1):8.

47. Nierobisz LS, Felts JV, Mozdziak PE. Apoptosis and macrophage infiltration occur simultaneously and present a potential sign of muscle injury in skeletal muscle of nutritionally compromised, early post-hatch turkeys. Comp Biochem Physiol B Biochem Mol Biol. 2009;153(1):61-5.

48. Kääriäinen $\mathrm{M}$, Järvinen $\mathrm{T}$, Järvinen $\mathrm{M}$, Rantanen J, Kalimo $\mathrm{H}$. Relation between myofibers and connective tissue during muscle injury repair Scand J Med Sci Sports. 2000;10(6):332-7.

49. Braun T, Gautel M. Transcriptional mechanisms regulating skeletal muscle differentiation, growth and homeostasis. Nat Rev Mol Cell Biol. 2011;12(6): 349-61.

50. Schiaffino S, Sandri M, Murgia M. Activity-dependent signaling pathways controlling muscle diversity and plasticity. Physiology (Bethesda). 2007;22:269-78.

51. Qi YX, Zhang XH, Wang YQ, Pang YZ, Zhang ZB, Zhang TL, Zhang ZX. Expression of MMP-1, -2 , and -8 in longissimus dorsi muscle and their relationship with meat quality traits in cattle. Genet Mol Res. 2016;15(1): 15017593. 
52. Weston A, Rogers $R$, Althen TG. The role of collagen in meat tenderness Prof Anim Sci. 2002;18(2):107-11.

53. Schilling MW, Mink LE, Gochenour PS, Marriott NG, Alvarado CZ. Utilization of pork collagen for functionality improvement of boneless cured ham manufactured from pale, soft, and exudative pork. Meat Sci. 2003;65(1):547-53.

54. Daigle SP, Schilling MW, Marriott NG, Wang H, Barbeau WE, Williams RC. PSE-like Turkey breast enhancement through adjunct incorporation in a chunked and formed deli roll. Meat Sci. 2005;69(2):319-24.

55. Huff-Lonergan E, Lonergan SM. Mechanisms of water-holding capacity of meat: the role of postmortem biochemical and structural changes. Meat Sci. 2005:71(1):194-204.

56. Kristensen L, Purslow PP. The effect of ageing on the water-holding capacity of pork: role of cytoskeletal proteins. Meat Sci. 2001;58(1):17-23.

57. Hynes RO. Integrins: versatility, modulation, and signaling in cell adhesion. Cell. 1992:69(1):11-25.

58. van der Flier A, Sonnenberg A. Function and interactions of integrins. Cell Tissue Res. 2001:305(3):285-98.

59. Lawson MA. The role of integrin degradation in post-mortem drip loss in pork. Meat Sci. 2004;68(4):559-66.

60. Zhang WG, Lonergan SM, Gardner MA, Huff-Lonergan E. Contribution of postmortem changes of integrin, desmin and $\mu$-calpain to variation in water holding capacity of pork. Meat Sci. 2006;74(3):578-85.

61. Oh JH, Kim YK, Jung JY, Shin JE, Kim KH, Cho KH, Eun HC, Chung JH. Intrinsic aging-and photoaging-dependent level changes of glycosaminoglycans and their correlation with water content in human skin. J Dermatol Sci. 2011;62(3):192-201.

62. Pinheiro MC, Mora OA, Caldini EG, Battlehner CN, Joazeiro PP, Toledo OM. Ultrastructural, immunohistochemical and biochemical analysis of glycosaminoglycans and proteoglycans in the mouse pubic symphysis during pregnancy. Cell Biol Int. 2005;29(6):458-71.

63. Jiang $S$, Jiang Z, Zhou G, Lin Y, Zheng CJJA. Effects of dietary isoflavone supplementation on meat quality and oxidative stability during storage in lingnan yellow broilers. J Integr Agr. 2014;13(2):387-93.

64. Loeffen JL, Smeitink JA, Trijbels JM, Janssen AJ, Triepels RH, Sengers RC, van den Heuvel LP. Isolated complex I deficiency in children: clinical, biochemical and genetic aspects. Hum Mutat. 2000;15(2):123-34.

65. Smeitink J, van den Heuvel L. Human mitochondrial complex I in health and disease. Am J Hum Genet. 1999;64(6):1505-10.

66. Distelmaier F, Koopman WJ, van den Heuvel LP, Rodenburg RJ, Mayatepek E, Willems PH, Smeitink JA. Mitochondrial complex I deficiency: from organelle dysfunction to clinical disease. Brain. 2009;132(Pt 4):833-42.

67. Perier C, Tieu K, Guégan C, Caspersen C, Jackson-Lewis V, Carelli V, Martinuzzi A, Hirano M, Przedborski S, Vila M. Complex I deficiency primes Bax-dependent neuronal apoptosis through mitochondrial oxidative damage. Proc Natl Acad Sci U S A. 2005;102(52):19126-31.

68. Ponsuksili S, Jonas E, Murani E, Phatsara C, Srikanchai T, Walz C, Schwerin M, Schellander K, Wimmers K. Trait correlated expression combined with expression QTL analysis reveals biological pathways and candidate genes affecting water holding capacity of muscle. BMC Genomics. 2008;9:367.

69. Vargas-Galicia AJ, Sosa-Montes E, Rodríguez-Ortega LT, Pro-Martinez A, RuizFeria CA, González-Cerón F, Gallegos-Sánchez J, Arreola-Enríquez J, BautistaOrtega J. Effect of litter material and stocking density on bone and tendon strength, and productive performance in broilers. Can J Anim Sci. 2017; 97(4):673-82.

70. Wu Y, Wang Y, Yin D, Wu W, Sun X, Zhang Y, Guo X, Chen J, Yuan J. Effect of supplementation of nicotinamide and sodium butyrate on the growth performance, liver mitochondrial function and gut microbiota of broilers at high stocking density. Food Funct. 2019;10(11):7081-90.

71. Wu Y, Wang Y, Wu W, Yin D, Sun X, Guo X, Chen J, Mahmood T, Yan L, Yuan J. Effects of nicotinamide and sodium butyrate on meat quality and muscle ubiquitination degradation genes in broilers reared at a high stocking density. Poult Sci. 2020;99(3):1462-70.

72. National Research Council. Nutrient requirements of poultry. 9th ed. Washington, DC: National Academy Press; 1994

73. Liu Y, Yuan JM, Zhang LS, Zhang YR, Cai SM, Yu JH, Xia ZF. Effects of tryptophan supplementation on growth performance, antioxidative activity, and meat quality of ducks under high stocking density. Poult Sci. 2015;94(8): 1894-901.

74. Cai K, Shao W, Chen X, Campbell YL, Nair MN, Suman SP, Beach CM, Guyton MC, Schilling MW. Meat quality traits and proteome profile of woody broiler breast (pectoralis major) meat. Poult Sci. 2018;97(1):337-46.
75. Trapnell C, Pachter L, Salzberg SL. TopHat: discovering splice junctions with RNA-Seq. Bioinformatics. 2009;25(9):1105-11.

76. Li B, Dewey CN. RSEM: accurate transcript quantification from RNA-Seq data with or without a reference genome. BMC Bioinformatics. 2011:12:323.

77. Robinson MD, McCarthy DJ, Smyth GK. edgeR: a bioconductor package for differential expression analysis of digital gene expression data. Bioinformatics. 2010;26(1):139-40.

78. Xie C, Mao X, Huang J, Ding Y, Wu J, Dong S, Kong L, Gao G, Li CY, Wei L. KOBAS 2.0: a web server for annotation and identification of enriched pathways and diseases. Nucleic Acids Res. 2011;39(Web Server issue):W316-22.

\section{Publisher's Note}

Springer Nature remains neutral with regard to jurisdictional claims in published maps and institutional affiliations.

\section{Ready to submit your research? Choose BMC and benefit from:}

- fast, convenient online submission

- thorough peer review by experienced researchers in your field

- rapid publication on acceptance

- support for research data, including large and complex data types

- gold Open Access which fosters wider collaboration and increased citations

- maximum visibility for your research: over $100 \mathrm{M}$ website views per year

At BMC, research is always in progress.

Learn more biomedcentral.com/submissions 